\title{
LIFE-CYCLE COSTING OF FOOD WASTE MANAGEMENT IN DENMARK: IMPORTANCE OF INDIRECT EFFECTS
}

VERONICA MARTINEZ-SANCHEZ ${ }^{*}{ }^{1}$, DAVIDE TONINI ${ }^{1}$, FLEMMING MØLLER ${ }^{2}$ AND THOMAS FRUERGAARD ASTRUP ${ }^{1}$

*) Corresponding author: vems@env.dtu.dk

${ }^{1}$ Technical University of Denmark, Department of Environmental Engineering, Miljoevej, Building 113, 2800 Kgs. Lyngby, Denmark

${ }^{2}$ Aarhus University, Department of Environmental Science, Frederiksborgvej 399, 4000 Roskilde, Denmark

This supporting information is 33 pages long and contains 16 tables and 3 figures. 


\section{Contents}

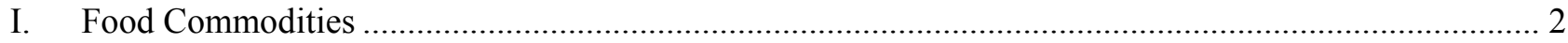

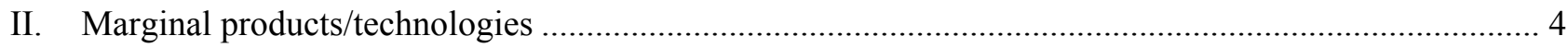

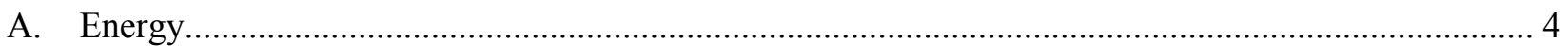

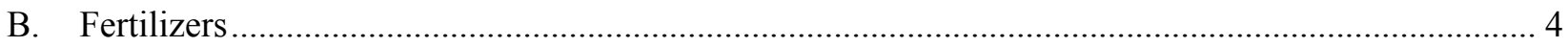

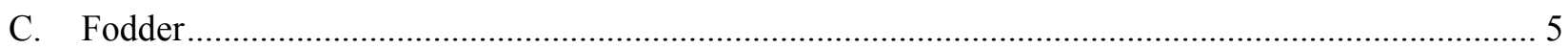

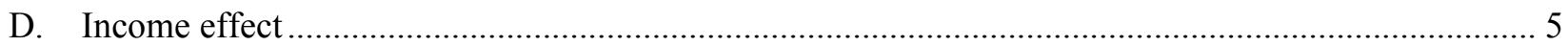

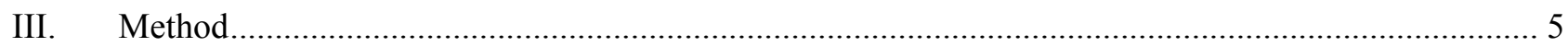

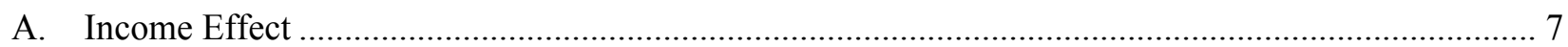

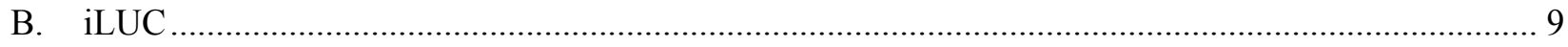

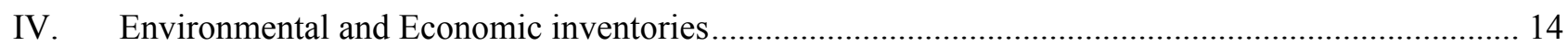

V. Upstream food commodities - Factor prices \& Ecoinvent names ...................................................... 17

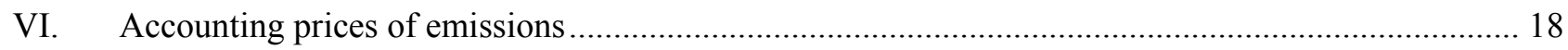

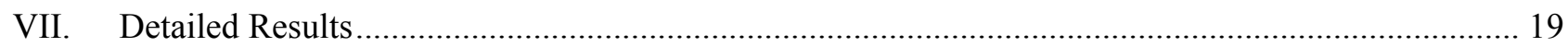

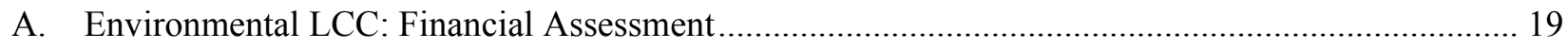

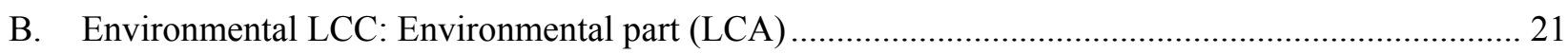

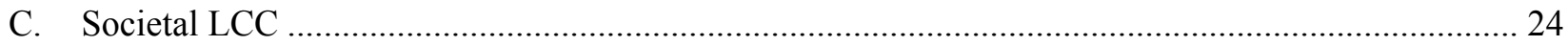

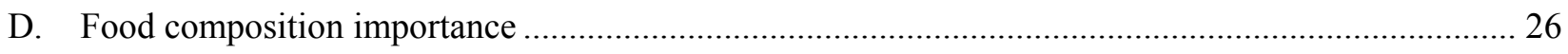

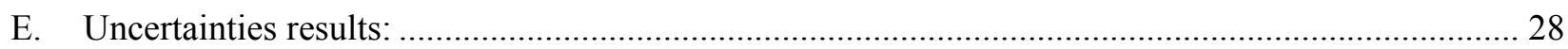

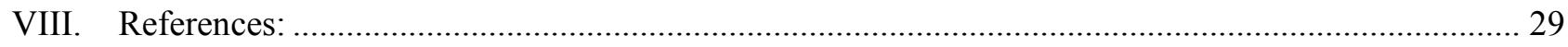




\section{Food Commodities}

To identify the food commodities found in the edible food waste, we used the amounts given by ${ }^{1,2}$ for the different food groups (e.g., fruits or bread/cake). We then calculated the final commodities with annual household consumption data from Statistics Denmark. ${ }^{3,4}$

The data from Statistics Denmark included: 1) annual consumption of food from (FU5 2010:2012) reported in DKK household ${ }^{-1}$ year $^{-1}, 2$ ) variable list of detail commodities for each group reported in FU5 and 3) average prices for food commodities in 2011 (DKK/kg). Even if the dataset "2)" was really detailed, "3)" was only available for some food commodities, so the food groups were split into commodities that were present in "2)" and "3)". Once the food commodities were selected, we found the amounts dividing "2)" by "3)" and then we calculated the ratios.

The data from ${ }^{1,2}$ was simplified by merging: i) processed and un-processed food, ii) cooked and uncooked food and iii) packed and unpacked bread. In addition the shares of "breakfast products", “other dry products", “other", "ready meals-(un)opened", "lunch leftover" and "bread with spreads" were distributed among the rest of commodities (accordingly with their shares). After this step, we excluded food commodities whose contribution in the edible food waste (either vegetable or animal) was lower than $10 \%$ and again their shares were distributed among the other commodities according with their shares. An exception was "fish" whose ratio was 5\%, but it was nevertheless included to assess its impact. For the modelling, we assumed that: 1) Danish pastry was merged with bread and 2) Spreads were assumed butter.

\section{- Sensitivity analysis on the food commodities composition:}

To assess the importance of the composition of the food commodities, we performed a sensitivity analysis with a different composition of food commodities following the approach of ${ }^{5}$, i.e. multiplying the loss rates reported by ${ }^{6}$ and ${ }^{7}$ by the average consumption in Danish households (same commodities used in the Baseline results), see Table S1. 
Table S1: Columns 1-3: Ratio of edible and inedible fractions for vegetable food waste and animal-derived food waste. Column 4: food commodities used in the study. Column 5: food composition assumed in the main results calculated from ${ }^{\mathbf{1}}$ and the adjustments mentioned above. To calculate the alternative food composition discussed in section "importance of the food commodities" and shown in column 9 we used: 1) food consumed per household in Denmark from Danish Statistics ${ }^{3,4}$ (column 6), avoidable Losses for each food commodity from Beretta et al. ${ }^{5}$ (column 7), the calculated amount of avoidable food waste for each commodity (column 8).

\begin{tabular}{|c|c|c|c|c|c|c|c|c|}
\hline & $\begin{array}{r}\text { Edible/Ir } \\
(\%) \mathrm{frc} \\
\end{array}$ & & $\begin{array}{c}\text { Food } \\
\text { commodities }\end{array}$ & $\begin{array}{c}\text { Baseline Food } \\
\text { composition (\%) }\end{array}$ & $\begin{array}{l}\text { Food consumption } \\
\left(\mathrm{kg} \mathrm{hh}^{-1} \mathrm{y}^{-1}\right) \text { from }^{3,4}\end{array}$ & $\begin{array}{l}\text { Avoidable }(\%) \\
\text { from }\end{array}$ & $\begin{array}{l}\text { Avoidable } \\
\left(\mathrm{kg} \mathrm{hh}^{-1} \mathrm{y}^{-1}\right)\end{array}$ & $\begin{array}{l}\text { Alternative Food } \\
\text { composition }(\%)\end{array}$ \\
\hline \multirow{13}{*}{ 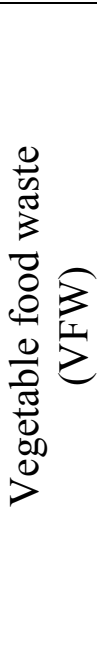 } & \multirow[t]{12}{*}{ Edible } & \multirow[t]{12}{*}{50} & Orange & 4.7 & 30.20 & 19 & 5.74 & 5 \\
\hline & & & Banana & 3.4 & 19.25 & 19 & 3.66 & 3 \\
\hline & & & Apple & 3.9 & 22.55 & 24 & 5.41 & 5 \\
\hline & & & Grapes & 2.8 & 23.12 & 19 & 4.39 & 4 \\
\hline & & & Kiwi & 2.3 & 17.91 & 19 & 3.40 & 3 \\
\hline & & & Carrots & 16.5 & 100.85 & 14 & 14.12 & 13 \\
\hline & & & Potatoes & 3.6 & 56.75 & 17 & 9.87 & 9 \\
\hline & & & Cabbage & 8.8 & 36.31 & 21 & 7.62 & 7 \\
\hline & & & Tomatoes & 13.5 & 40.11 & 21 & 8.42 & 8 \\
\hline & & & Bread & 30.4 & 125.84 & 33 & 41.53 & 38 \\
\hline & & & Rice & 5.1 & 6.03 & 29 & 1.75 & 2 \\
\hline & & & Pasta & 5.1 & 10.19 & 29 & 2.96 & 3 \\
\hline & Inedible & 50 & & & & & & \\
\hline \multirow{10}{*}{ 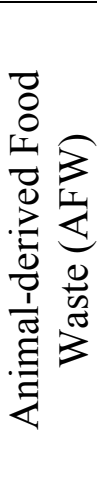 } & \multirow[t]{9}{*}{ Edible } & \multirow[t]{9}{*}{75} & Eggs & 6.7 & 14.37 & 9 & 1.29 & 4 \\
\hline & & & Beef meat & 10.5 & 23.04 & 9 & 2.07 & 6 \\
\hline & & & Pork meat & 8.3 & 17.76 & 13 & 2.33 & 7 \\
\hline & & & Chicken meat & 4.0 & 11.91 & 13 & 1.52 & 5 \\
\hline & & & Fish - Salmon & 1.3 & 12.60 & 11 & 1.32 & 4 \\
\hline & & & Milk & 31.7 & 177.25 & 9 & 15.95 & 49 \\
\hline & & & Yoghurt & 8.4 & 45.68 & 9 & 4.11 & 13 \\
\hline & & & Cheese $(45 \%)$ & 4.4 & 22.91 & 14 & 3.21 & 10 \\
\hline & & & Butter & 24.2 & 8.06 & 8 & 0.65 & 2 \\
\hline & Inedible & 25 & & & & & & \\
\hline
\end{tabular}




\section{Marginal products/technologies}

Table S2 summarizes the marginal technologies/processes considered in this assessment. The "marginal" is defined as that technology/process that is more likely to respond to changes induced in the demand/supply of a specific service/product (e.g. food waste) following the definition given in 8,9 .

Table S2: Marginal technologies/products considered.

\begin{tabular}{|l|l|l|}
\hline Product/service & Market scope & Marginal technology/product \\
\hline Electricity & National (DK) & Coal-fired power plants \\
District heating & National (DK) & Natural gas boilers \\
Energy-feed & Global & Maize \\
N-fertilizers & Global & Urea \\
P-fertilizer & Global & Diammonium phosphate \\
K-fertilizer & Global & $\mathrm{K}_{2} \mathrm{O}$ \\
\hline
\end{tabular}

\section{A. Energy}

It was assumed that in a long-term perspective energy from waste contributes to the decommissioning of fossil-based energy production capacities (both electricity and heat) as these technologies are generally intended to be phased out in order to comply with political $\mathrm{CO}_{2}$ reduction targets. Thus, scenarios generating energy from the waste (e.g. incineration and anaerobic digestion) were credited with the substitution of fossil fuel-based energy production. Coal-fired power plants were assumed as marginal technologies for electricity production, following Danish government's targets to phase-out coal by $2030 .{ }^{10}$ Marginal heat was assumed to originate from natural gas boilers. This choice is supported by projections from ${ }^{11}$ where natural gas clearly appears as the preferred fuel for new installations and capacity expansions.

\section{B. Fertilizers}

The digestate produced from anaerobic digestion was used as organic fertilizer (for $\mathrm{N}, \mathrm{P}$, and $\mathrm{K}$ ), which avoided marginal mineral N, P, and K fertilizers to be produced and used, based on the content of $\mathrm{N}, \mathrm{P}$, and $\mathrm{K}$ of the digestate. The marginal N, P, and $\mathrm{K}$ fertilizers considered were urea, diammonium phosphate (DAP), and potassium chloride as in ${ }^{12}$. This choice is supported by 2000 2010 trends in demand/consumption(IFA 2014) and by projected capacity installation elaborated 
based on statistics from International Fertilizer Association (IFA). ${ }^{13}$ The LCI for urea, DAP, and potassium chloride was based on Ecoinvent data for the production of these fertilizers.

\section{Fodder}

With respect to the substitution of conventional fodder, only the energy-part of the animal diet was considered as the protein-content of vegetable food waste is generally low (ca. $10 \%$, as opposite to animal waste which contains ca. 34\%). The marginal energy-fodder was assumed to be maize-

fodder conformingly with ${ }^{12}$. The substitution was therefore based upon the energy-feed content of the mixed vegetable waste relative to that of maize, both calculated as Scandinavian Feed Units as done in ${ }^{12}$.

In this study, the SFU of the mixed vegetable waste was quantified to $1.06 \mathrm{SFU} \mathrm{kg}^{-1}$ Dry Matter (DM) food waste, based on the weighted average of the SFU of each individual food commodity composing the mix (e.g., tomatoes, bread, potatoes, etc.). The SFU of each commodity was calculated based on the composition retrieved from ${ }^{14}$. For maize, instead, the SFU equaled 1.21 SFU kg ${ }^{-1} \mathrm{DM}$ based on its typical composition from ${ }^{15}$. Thus, $1 \mathrm{~kg}$ DM food waste-fodder substitutes for $0.87 \mathrm{~kg}$ DM maize-fodder (on a wet basis, $1 \mathrm{~kg} \mathrm{ww}$ food waste-fodder substituted for $0.38 \mathrm{~kg}$ ww maize-fodder, having vegetable food waste mix and maize a dry matter content of $36 \%$ and $86 \%$, respectively).

\section{Income effect}

To estimate the marginal consumption induced/reduced by the change in household expenses in comparison with Sc-IN, we used the approach of ${ }^{16}$ and the data from Statistics Denmark on households annual consumption (by type), group of households and price unit (FU5) in the year 2011:2013. See section SIIIA for a description of the method used.

\section{Method}

Table S3 described the activities included in the assessments under Environmental LCC and Societal LCC. 
Table S3: Assessment criteria, indicators, cost types, agents involved and "items" included. *including emissions from the material provision related to the food commodities associated with the edible food waste.

\begin{tabular}{|c|c|c|c|c|c|c|c|c|}
\hline & \multirow[t]{2}{*}{ Indicators } & \multirow[t]{2}{*}{ Cost types } & \multicolumn{6}{|c|}{ Agents or stakeholders involved in the system } \\
\hline & & & $\begin{array}{l}\text { Waste } \\
\text { Management } \\
\text { System (WMS) }\end{array}$ & Food Industry & $\begin{array}{l}\text { Energy } \\
\text { sector }\end{array}$ & Agriculture & $\begin{array}{l}\text { General } \\
\text { Industry } \\
\text { (income } \\
\text { effect) }\end{array}$ & State \\
\hline \multirow{3}{*}{ 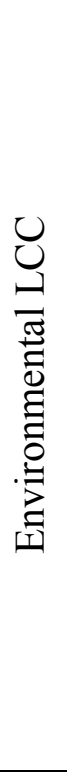 } & \multirow[t]{2}{*}{$\begin{array}{l}\text { Financial } \\
\text { Assessment }\end{array}$} & Budget costs & $\begin{array}{l}\text { Factor prices of } \\
\text { the goods used } \\
\text { in the WMS }\end{array}$ & $\begin{array}{l}\text { Factor prices of } \\
\text { the food } \\
\text { commodities }\end{array}$ & $\begin{array}{l}\text { Factor } \\
\text { prices of } \\
\text { energy }\end{array}$ & $\begin{array}{l}\text { Factor prices of } \\
\text { NPK and maize }\end{array}$ & $\begin{array}{l}\text { Difference in } \\
\text { cost between } \\
\text { the baseline } \\
\text { scenario and } \\
\text { the } \\
\text { alternative }\end{array}$ & \\
\hline & & Transfers & & & & & & $\begin{array}{l}\text { Taxes } \\
\text { revenues, } \\
\text { subsidies } \\
\text { and tax } \\
\text { exemptions } \\
\end{array}$ \\
\hline & LCA & $\begin{array}{l}\text { Emissions } \\
\text { related to: }\end{array}$ & WMS* & $\begin{array}{l}\text { - Food } \\
\text { production* } \\
\text { - iLUC from food } \\
\text { production }\end{array}$ & $\begin{array}{l}\text { Marginal } \\
\text { energy } \\
\text { generation }\end{array}$ & $\begin{array}{l}\text { Production and } \\
\text { use of mineral } \\
\text { NPK and maize }\end{array}$ & $\begin{array}{l}\text { Marginal } \\
\text { consumption } \\
\text { related to the } \\
\text { Income } \\
\text { effect }\end{array}$ & NA \\
\hline \multirow[b]{2}{*}{ 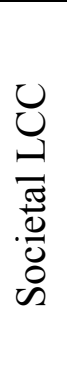 } & \multirow{2}{*}{$\begin{array}{l}\text { Welfare } \\
\text { Economic } \\
\text { Assessment }\end{array}$} & Budget costs & \multicolumn{5}{|c|}{$\begin{array}{l}\text { Same as the "Budget costs" of the Environmental LCC but accounted for in } \\
\text { accounting prices, i.e. factor prices times the Net Tax Factor (NTF). }\end{array}$} & NA \\
\hline & & $\begin{array}{l}\text { Externality } \\
\text { costs }\end{array}$ & $\begin{array}{l}\text { - LCA in } \\
\text { accounting } \\
\text { prices } \\
\text { - Transport } \\
\text { externality } \\
\text { costs }\end{array}$ & $\begin{array}{l}\text { - LCA in } \\
\text { accounting prices } \\
\text { - Ecosystem losses } \\
\text { related to iLUC }\end{array}$ & $\begin{array}{l}\text { LCA in } \\
\text { accounting } \\
\text { prices }\end{array}$ & $\begin{array}{l}\text { - LCA in } \\
\text { accounting } \\
\text { prices } \\
\text { - Ecosystem } \\
\text { losses related } \\
\text { to iLUC }\end{array}$ & $\begin{array}{l}\text { LCA in } \\
\text { accounting } \\
\text { prices }\end{array}$ & $\begin{array}{l}\text { Tax } \\
\text { distorsion } \\
\text { loss }\end{array}$ \\
\hline
\end{tabular}




\section{A. Income Effect}

The marginal consumption was calculated with the following approach (Figure S1):

1) Matching the categories used in the Danish expenditure statistics and the Input-Output tables from ${ }^{17}$ regarding households consumptions (Table S4).

2) Calculating the variation on the expenses for each of the 9 item (good/service) between adjacent income groups and divide them by the variation on total expenditure between the same income groups. These percentages represent the marginal consumptions of each income group. Step 1 of Figure S1.

3) Calculating the weighted marginal consumption in Denmark, using the marginal consumptions and the population in each income group. Step 2 of Figure S1.

0) RAW DATA - Annual Expenses per income group and number of households per income group from Danish Expenditure Statistics of each of the 9 items matched with the input/output tables data included in Table S4.

\begin{tabular}{|l|c|c|c|c|c|}
\hline Item (Good/service) & $\mathrm{IG}^{1}$ & $\mathrm{IG}^{2}$ & $\mathrm{IG}^{3}$ & $\mathrm{IG}^{4}$ & $\mathrm{IG}^{5}$ \\
\hline $\mathrm{I}_{1}$ & $E_{1}^{1}$ & $E_{1}^{2}$ & $E_{1}^{3}$ & $E_{1}^{4}$ & $E_{1}^{5}$ \\
\hline $\mathrm{I}_{2}$ & $E_{2}^{1}$ & $E_{2}^{2}$ & $E_{2}^{3}$ & $E_{2}^{4}$ & $E_{2}^{5}$ \\
\hline$\ldots$ & & & & & \\
\hline $\mathrm{I}_{9}$ & $E_{9}^{1}$ & $E_{9}^{2}$ & $E_{9}^{3}$ & $E_{9}^{4}$ & $E_{9}^{5}$ \\
\hline Total Expenses & $\mathrm{TE}^{1}$ & $\mathrm{TE}^{2}$ & $\mathrm{TE}^{3}$ & $\mathrm{TE}^{4}$ & $\mathrm{TE}^{5}$ \\
\hline Households & $\mathrm{HH}^{1}$ & $\mathrm{HH}^{2}$ & $\mathrm{HH}^{3}$ & $\mathrm{HH}^{4}$ & $\mathrm{HH}^{5}$ \\
\hline
\end{tabular}

$I_{i}=$ Item $i$, where $i$ goes from 1 to $9\left(1^{\text {st }}\right.$ column Figure $\left.\mathbf{S} 1\right)$

$\mathrm{IG}^{\mathrm{j}}=$ income group $\mathrm{j}$, where $\mathrm{j}$ goes from 1 to 5

$E_{i}^{j}=$ Expenses of income group $\mathrm{j}$ on item $\mathrm{i}$ (DKK/year)

$\mathrm{TE}^{\mathrm{j}}=$ total expenses of income group $\mathrm{j}$ (DKK/year) that results from the sum of all the expenses, i.e. $T E^{j}=\sum_{1}^{9} E_{i}^{j}$

$\mathrm{HH}^{\mathrm{j}}=$ number of households in income group $\mathrm{j}$

The total households in Denmark (THH) correspond to the sum of the households in each income group, i.e. $T H H=\sum_{1}^{5} H H^{j}$

\section{1) MARGINAL CONSUMPTION OF EACH INCOME GROUP}

\begin{tabular}{|l|l|l|l|l|}
\hline Item (Good/service) & $\mathrm{IG}^{1}$ & $\mathrm{IG}^{2}$ & $\mathrm{IG}^{3}$ & $\mathrm{IG}^{4}$ \\
\hline $\mathrm{I}_{1}$ & $\frac{E_{1}^{2}-E_{1}^{1}}{T E^{2}-T E^{1}}$ & $\frac{E_{1}^{3}-E_{1}^{2}}{T E^{3}-T E^{2}}$ & $\frac{E_{1}^{4}-E_{1}^{3}}{T E^{4}-T E^{3}}$ & $\frac{E_{1}^{5}-E_{1}^{4}}{T E^{5}-T E^{4}}$ \\
\hline $\mathrm{I}_{2}$ & $\frac{E_{2}^{2}-E_{2}^{1}}{T E^{2}-T E^{1}}$ & $\frac{E_{2}^{3}-E_{2}^{2}}{T E^{3}-T E^{2}}$ & $\frac{E_{2}^{4}-E_{2}^{3}}{T E^{4}-T E^{3}}$ & $\frac{E_{2}^{5}-E_{2}^{4}}{T E^{5}-T E^{4}}$ \\
\hline$\ldots$ & & & & \\
\hline $\mathrm{I}_{9}$ & $\frac{E_{9}^{2}-E_{9}^{1}}{T E^{2}-T E^{1}}$ & $\frac{E_{9}^{3}-E_{9}^{2}}{T E^{3}-T E^{2}}$ & $\frac{E_{9}^{4}-E_{9}^{3}}{T E^{4}-T E^{3}}$ & $\frac{E_{9}^{5}-E_{9}^{4}}{T E^{5}-T E^{4}}$ \\
\hline
\end{tabular}

It is assumed that an additional unit of disposal income affects the consumptions of all income groups.

The new consumption of an income group $j\left(I^{j}\right)$ is assumed equal to the consumption of the adjacent income group $\left(\mathrm{IG}^{\mathrm{j}+1}\right)$.

The marginal consumption of this income group is calculated with the different in the consumptions of each item divided by the difference in the total expenses.

2) WEIGHTED MARGINAL CONSUMPTION - Based on the amount of households per income group

\begin{tabular}{|l|l|}
\hline Item (Good/service) & Item Ratio in the weighted marginal consumption \\
\hline $\mathrm{I}_{1}$ & $\frac{E_{1}^{2}-E_{1}^{1}}{T E^{2}-T E^{1}} \cdot\left(\frac{H H^{1}}{T H H}\right)+\frac{E_{1}^{3}-E_{1}^{2}}{T E^{3}-T E^{2}} \cdot\left(\frac{H H^{2}}{T H H}\right)+\frac{E_{1}^{4}-E_{1}^{3}}{T E^{4}-T E^{3}} \cdot\left(\frac{H H^{3}}{T H H}\right)+\frac{E_{1}^{5}-E_{1}^{4}}{T E^{5}-T E^{4}} \cdot\left(\frac{H H^{4}+H H^{5}}{T H H}\right)$ \\
\hline$\ldots$ & $\frac{E_{9}^{2}-E_{9}^{1}}{T E^{2}-T E^{1}} \cdot\left(\frac{H H^{1}}{T H H}\right)+\frac{E_{9}^{3}-E_{9}^{2}}{T E^{3}-T E^{2}} \cdot\left(\frac{H H^{2}}{T H H}\right)+\frac{E_{9}^{4}-E_{9}^{3}}{T E^{4}-T E^{3}} \cdot\left(\frac{H H^{3}}{T H H}\right)+\frac{E_{9}^{5}-E_{9}^{4}}{T E^{5}-T E^{4}} \cdot\left(\frac{H H^{4}+H H^{5}}{T H H}\right)$ \\
\hline $\mathrm{I}_{9}$
\end{tabular}

It was assumed that the marginal consumption of income group 5 was the same as the marginal consumption of income 4.

Figure S1: Calculation procedure to identify the marginal consumption from the Danish expenditure statistics (Raw Data). 
Table S4: Matching between Danish statistics data and IO tables and the composition of the marginal consumption (income effect distribution) estimated and used in this study.

\begin{tabular}{|c|c|c|c|}
\hline $\begin{array}{l}\text { Items number and } \\
\text { name in the study }\end{array}$ & Danish Statistics Item $^{4}$ & $\begin{array}{c}\text { Input-Output } \\
\text { tables (EU 27) }\end{array}$ & $\begin{array}{r}\text { Marginal } \\
\text { Consumption }\end{array}$ \\
\hline 1.Clothing & $\begin{array}{l}\text { Clothing and Footwear (categories } \\
3111,3121-3123,3131,3141,3211- \\
3213,3221 \text { ) }\end{array}$ & $\begin{array}{l}133 \text { Household } \\
\text { use, Clothing, } \\
\text { EU27 }\end{array}$ & $6 \%$ \\
\hline 2.Communication & $\begin{array}{l}\text { Purchase of Vehicles (categories } 7111 \text {, } \\
7121,7131 \text { ), Other transport services } \\
\text { and communication (categories 7211- } \\
7221,7231,7241,7251,7321,7331 \text {, } \\
7341,7351,7361,8111,8211,8311 \text { ) }\end{array}$ & $\begin{array}{l}134 \text { Household } \\
\text { use, } \\
\text { Communication, } \\
\text { EU27 }\end{array}$ & $22 \%$ \\
\hline 3.Education & $\begin{array}{l}\text { Other goods and services (categories: } \\
9721,9741,9751 \text { and } 9941)\end{array}$ & $\begin{array}{l}135 \text { Household } \\
\text { use, Education, } \\
\text { EU27 }\end{array}$ & $3 \%$ \\
\hline 4.Health Care & $\begin{array}{l}\text { Medical products, services and } \\
\text { physicians (categories } 6111,6121, \\
6131,6211,6221,6232-6233 \text { and } \\
6311 \text { ) }\end{array}$ & $\begin{array}{l}136 \text { Household } \\
\text { use, Health care, } \\
\text { EU27 }\end{array}$ & $2 \%$ \\
\hline 5.Housing & $\begin{array}{l}\text { Rent Housing (categories 4111, 4112, } \\
4121,4211,4215,4221-4222,4225, \\
4311,4321,4411,4421,4425,4431, \\
4441) \text {, Electricity and fuels (categories } \\
\text { 4511, 4521,4522,4531,4541,4551) } \\
\text { Furniture, Furnishings and households } \\
\text { services (categories: 5111, 5121, 5131, } \\
5211,5311-5317,5321,5331,5411- \\
5413,5511,5521,5611-5612,5621- \\
5622) .\end{array}$ & $\begin{array}{l}137 \text { Household } \\
\text { use, Housing, } \\
\text { EU27 }\end{array}$ & $31 \%$ \\
\hline 6.Hygiene & $\begin{array}{l}\text { Other goods and services (categories } \\
\text { 9912-9913) }\end{array}$ & $\begin{array}{l}138 \text { Household } \\
\text { use, Hygiene, } \\
\text { EU27 }\end{array}$ & $1 \%$ \\
\hline 7.Leisure & $\begin{array}{l}\text { Tobacco (categories 2211-2213) and } \\
\text { Other goods and services (9811-9812, } \\
9821,9911,9921,9931-9932)\end{array}$ & $\begin{array}{l}139 \text { Household } \\
\text { use, Leisure, EU27 }\end{array}$ & $16 \%$ \\
\hline 8.Meals & $\begin{array}{l}\text { Food (categories from } 1111 \text { to } 1199 \text { ) } \\
\text { and Beverages (categories } 1211-1213 \text {, } \\
1221-1224,2111,2121-2122,2131 \text { and } \\
2199) \text {. }\end{array}$ & $\begin{array}{l}140 \text { Household } \\
\text { use, Meals, EU27 }\end{array}$ & $13 \%$ \\
\hline 9.Security & $\begin{array}{l}\text { Other goods and services (categories } \\
\text { 9951-9955, 9962, 9972, 9981) } \\
\text { (e.g., insurances, financial } \\
\text { intermediation, public services and } \\
\text { security) }\end{array}$ & $\begin{array}{l}141 \text { Household } \\
\text { use, Security, } \\
\text { EU27 }\end{array}$ & $5 \%$ \\
\hline
\end{tabular}




\section{B. iLUC}

Figure S2 describes the procedure used to calculate costs and impacts of iLUC in both LCCs.

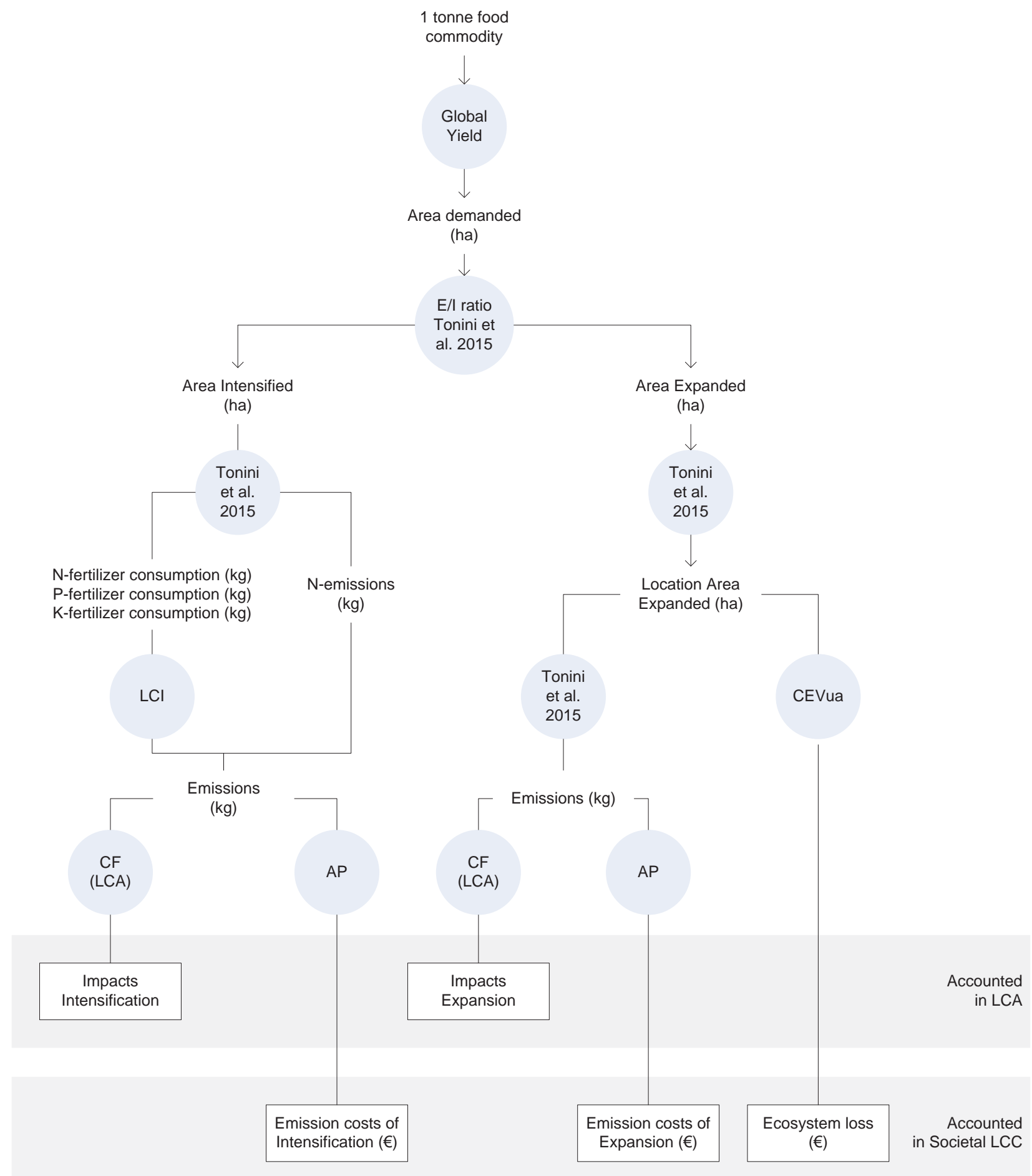

Figure S2: iLUC calculation approach used in the investigation. E/I ratio = Expansion/Intensification ratio, $\mathrm{LCI}=$ Life Cycle Inventory, CEVua $=$ Combined Ecosystem Value per unit area, $\mathrm{CF}(\mathrm{LCA})=$ Characterization Factors used in the LCA, AP $=$ Accounting Prices. 
Several approaches for estimation of emissions from expansion and intensification have been proposed in literature ${ }^{18-22}$. In this study, we followed the approach outlined in Figure S1 based on Tonini et al. ${ }^{12}$ This included the assumption that demand for land had global effects (reflecting the global nature of agricultural commodity trading) and that iLUC effects. Modelling of the iLUC data provided in Table S5 included estimation of: 1) the share of intensification and expansion in the overall response to changes in demand for land agricultural land, 2) the geographical location of the expansion and affected biomes, 3 ) the changed flows of carbon and nitrogen as a result of the expansion, and 4) the increases in use of N, P, K fertilizer for intensification as well as the overall emissions associated with fertilizer use. The inventory data in Table S5 were based on deforestation data for the period 2000-2010 from FAO. The data applied here are comparable with other estimates in literature (e.g. ${ }^{23}$ ).

Table S5: Inventory for land-use (1 ha arable land demanded). For intensification N- emissions, $\mathrm{N}_{2} \mathrm{O}$ is reported as the sum of direct and indirect $\mathrm{N}_{2} \mathrm{O}$ emissions (from ${ }^{12}$ )

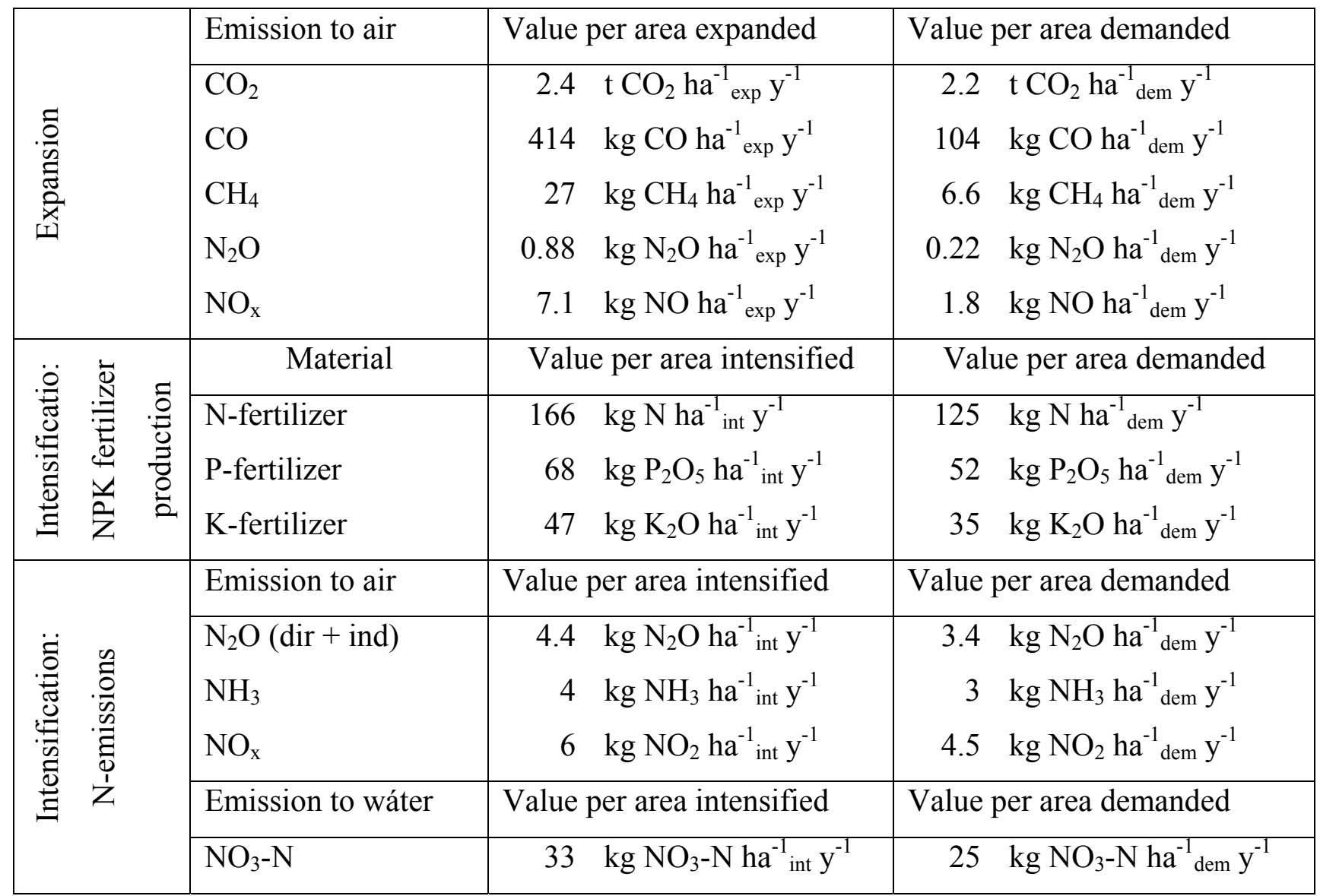


For the Societal LCC, we had two externality costs related to iLUC: one caused by the emissions during expansion and intensification, and the other related to the ecosystem loss. The externality costs of the emissions were calculated with the same iLUC emissions of the LCA (Table S5), but converted into accounting prices. For the ecosystem loss, we calculated total value of the ecosystem as a sum of all the ecosystem services provided by the ecosystem using the following approach:

1- Calculate the Combined Ecosystem Service Value provided by a unit area of ecosystem that resulted from the sum of all the services values provided by the ecosystem, Equation S1.

$$
C E S V_{u a}^{i}=\sum_{j}^{m} E S V_{u a}^{i j}
$$

Where:

$C E S V_{u a}^{i}=$ Combine Ecosystem Service Value per unit area (ua) of ecosystem $i$ per year $(€ /$ ha/year).

$E S V_{u a}^{i j}=$ Ecosystem Service Value of the service $j$ per unit area $(u a)$ of ecosystem $i$ per year $(€ /$ ha/year $)$

$j=$ ecosystem services, there are $m$ services provided by this combination

2- Calculate the Combined Ecosystem Service Value related to the production of commodity $a$, based on the area of ecosystem $i$ transformed because of the production of food commodity $a\left(A_{a}^{i}\right)$ and the combine ecosystem service value per unit area of the ecosystem $i\left(C E S V_{u a}^{i}\right)$, Equation S2.

$$
\operatorname{CESV}_{a}=\sum_{i}^{n} A_{a}^{i} \cdot \operatorname{CESV}_{u a}^{i}
$$

Where:

$C E S V_{\text {wheat }}=$ Combined Ecosystem Service Value related to cultivate 1 tonne of product $a$ $(€ / \mathrm{t}$ of $\mathrm{a})$

$A_{a}^{i}=$ Area of ecosystem i displaced to cultivate 1 tonne of a (ha/y/tonne $\left.a\right)$

$i=$ ecosystem displaced, there are $n$ ecosystem displaced in the production of product $a$.

Table S6 reports the Ecosystem Service Values for each region and service provided as well as the Combined Ecosystem Value per unit area. Due to the uncertainty related to the valuation techniques and the variability between studies, for each combination "biome-region-service" we used the median of the values reported in main results and max and min values only for discussion.

Such values were multiplied by the share of ecosystems affected by expansion that are summarized in Table S7. 
Table S6: Ecosystem use values per region and ecosystem service in $€ \mathrm{ha}^{-1} \mathrm{y}^{-1}$. Tropical forest (TRF) includes: Tropical evergreen forest, Tropical seasonal forest, Tropical open forest, Tropical moist forest, Tropical rain forest, Tropical dry forest. Temperate Forest includes: Temperate evergreen forest, Temperate seasonal forest, Temperate deciduous forest. GL $=$ Grassland, DS=dessert, OF $=$ Open forest, $\mathrm{PL}=$ Peatland, $\mathrm{TEGL}=$ Temperate grassland, $\mathrm{SL}=$ Shrubland, $\mathrm{MF}=$ Mountain forest, $\mathrm{TRGL}=$ tropical grassland, $\mathrm{TRW}=$ tropical woodland . TEV was excluded because of double counting

\begin{tabular}{|c|c|c|c|c|c|c|c|c|c|c|}
\hline \multicolumn{11}{|c|}{ Ecosystem values per region and ecosystem services and the Combine Ecosystem Value per unit area (CEVua) in $€$ ha $^{-1} \mathrm{y}^{-1}$} \\
\hline Region & Ecosystem & Climate & Food & Genepool & Medical & Raw materials & Recreation & CEVua & No Data & Ref. \\
\hline South & TRF & $202-14(89)$ & $912-1(56)$ & $146-1(1)$ & $716-0(6)$ & 230-1 (19) & $496-5(27)$ & $2701-21(200)$ & TEF and & 24-36 \\
\hline America & GL & \multicolumn{3}{|c|}{$118-68(68)$} & & & & $118-68(68)$ & DS & \\
\hline Central & TRF & 75 & $247-0(6)$ & $84-4(5)$ & $1520-5(762)$ & 72 & $1221-1(66)$ & $3220-157$ (988) & \multirow{2}{*}{$\begin{array}{c}\text { GL and } \\
\text { DS }\end{array}$} & \multirow{2}{*}{$37-48$} \\
\hline America & TEF & $77-15(42)$ & 247 & 4 & 5 & & $5-1(1)$ & $338-272(299)$ & & \\
\hline South- & TRF & \multirow{2}{*}{$963-0$ (454) } & \multirow{2}{*}{$144-6(10)$} & \multirow{2}{*}{$19-0(10)$} & \multirow{2}{*}{$48-0(3)$} & \multirow{2}{*}{$98-8(41)$} & \multirow{2}{*}{11} & \multirow{2}{*}{$1283-25(528)$} & \multirow{2}{*}{ PL } & $33,41,48-$ \\
\hline East Asia & OF & & & & & & & & & 58 \\
\hline \multirow{2}{*}{ Africa } & TRF & \multirow[t]{2}{*}{$117-2(88)$} & \multirow[t]{2}{*}{$41-0(2)$} & $19-2(4)$ & \multirow[t]{2}{*}{$180-0(26)$} & \multirow[t]{2}{*}{$46-2(8)$} & \multirow[t]{2}{*}{$157-1(13)$} & $559-6(142)$ & \multirow{2}{*}{ SL } & \multirow{2}{*}{$33,59-63$} \\
\hline & MF & & & 17 & & & & 17 & & \\
\hline \multirow{3}{*}{ Oceania } & TEF & 4 & 0 & 2 & & $3-1(1)$ & 1 & $10-8(8)$ & \multirow{3}{*}{ TRGL } & \multirow{3}{*}{$\begin{array}{c}33,46,64 \\
66\end{array}$} \\
\hline & TRF & 11 & 4 & $16-5(12)$ & $711-14(363)$ & 5 & 4 & $751-43$ (399) & & \\
\hline & TRW & & & & 2 & & & 1.9 & & \\
\hline
\end{tabular}


Table S7: Share of ecosystems affected by expansion from ${ }^{12}$.RF=Rain Forest, $M=$ Moist, $D=D r y$, $\mathrm{St}=$ Steppe, $\mathrm{Sh}=$ Shrub, $\mathrm{Dt}=$ Desert, $\mathrm{M}=$ Mountain.

\begin{tabular}{|c|c|c|c|c|c|c|c|c|c|}
\hline & & & $\mathrm{RF}$ & M & $\mathrm{D}$ & St & Sh & Dt & M \\
\hline \multirow{3}{*}{\multicolumn{2}{|c|}{ 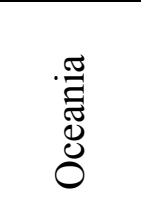 }} & Tropical & 0.01 & & 0.02 & & & & \\
\hline & & Subtropical & & & & 0.01 & & & \\
\hline & & Temperate + Boreal + Polar & & & & & & & \\
\hline \multirow{3}{*}{ 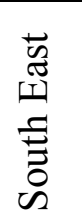 } & \multirow{3}{*}{$\frac{\frac{\pi}{2}}{4}$} & Tropical & 0.07 & 0.02 & 0.01 & & & 0.01 & \\
\hline & & Subtropical & & & & & & & \\
\hline & & Temperate + Boreal + Polar & & & & & & & \\
\hline \multirow{3}{*}{ 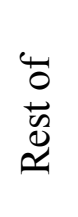 } & \multirow{3}{*}{$\frac{\pi}{\frac{\pi}{2}}$} & Tropical & & & & & & & \\
\hline & & Subtropical & & 0.01 & & & & & \\
\hline & & Temperate + Boreal + Polar & & & & & & & \\
\hline \multirow{3}{*}{\multicolumn{2}{|c|}{ 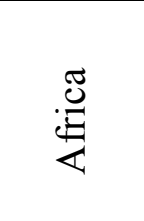 }} & Tropical & 0.11 & 0.09 & 0.10 & & 0.02 & & 0.01 \\
\hline & & Subtropical & & & & & & & \\
\hline & & Temperate + Boreal + Polar & & & & & & & \\
\hline \multirow{3}{*}{\multicolumn{2}{|c|}{ 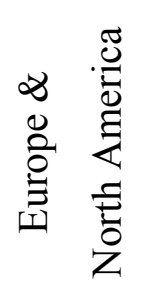 }} & Tropical & & & & & & & \\
\hline & & Subtropical & & & & & & & \\
\hline & & Temperate + Boreal + Polar & & & & & & & \\
\hline & \multirow{3}{*}{ 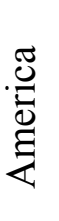 } & Tropical & 0.01 & 0.01 & & & & & 0.01 \\
\hline & & Subtropical & & & & & & & 0.01 \\
\hline & & Temperate + Boreal + Polar & & & & & & & \\
\hline \multirow{3}{*}{\multicolumn{2}{|c|}{ 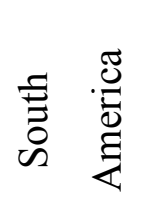 }} & Tropical & 0.21 & 0.04 & 0.04 & & 0.08 & & 0.01 \\
\hline & & Subtropical & & & & & & & \\
\hline & & Temperate + Boreal + Polar & & & & & & & \\
\hline
\end{tabular}




\section{Environmental and Economic inventories}

The environmental and economic inventories used in the study stem from ${ }^{67}$ and Table S8 summarizes specific parameters for this study.

- The source segregation included costs of bags and the emissions associated. Scenarios CD and AF included source separation of organic waste and vegetable food waste, respectively. No data was available for the sorting efficiencies of Scenario AF and we assumed $60 \%$ in SFH and $40 \%$ in $\mathrm{MFH}$.

- The collection included: capital costs, operation and maintenance costs (e.g. labor, fuel) and externality costs.

- The incineration accounted for all cost/revenues incurred by the incinerator operator. We assumed that all the scenarios used the same incineration plant, but the waste with higher LHV and met thermal capacity with less waste, see ${ }^{67}$.

- The anaerobic digestion accounted for costs of: pre-treatment of organic municipal waste with screw press and co-digestion of organic waste with manure. We assumed a state-of-theart plant with annual capacity of $300,000 \mathrm{Mg}$ to treat manure and organic waste and that $10 \%$ of the total capacity was used for organic waste and the rest for manure, see ${ }^{67}$.

- The economic and environmental data for: 1) Transportation of Bottom Ash and Fly Ash to final disposal, 2) bottom ash landfill and 3) neutralization of acid waste with fly ash stem from $^{67}$.

- Twenty minutes heating are enough for the required drying (up to $90 \%$ dry matter) hygienization to use vegetable food waste as animal fodder ${ }^{68}$. This can be done with thermal drying or electric heaters. We assumed electric heaters and we calculated the electric consumption (Q) to be $152 \mathrm{kWh} \mathrm{t}^{-1} \mathrm{ww}$ based on Eqs. S3-S5.

$$
\begin{aligned}
& -\quad=Q_{\text {water }}+Q_{\text {solid }} \\
& \text { - } \quad Q_{\text {water }}=m_{\text {water }} \cdot \frac{\Delta T}{790} \cdot t_{\text {heating }} \\
& \text { - } \quad Q_{\text {solid }}=m_{\text {solid }} \cdot \frac{\Delta T}{5040} \cdot t_{\text {heating }}
\end{aligned}
$$

Where;

$$
\begin{aligned}
& m_{\text {water }}=640 \mathrm{~kg} \text { water } / \text { tonne food waste }\left(m_{\text {solid }}=260 \mathrm{~kg} \text { solid } / \text { tonne food waste }\right) \\
& \Delta T=57.3^{\circ} \mathrm{C}\left(\mathrm{T} \text { input }=7.7^{\circ} \mathrm{C} \text { and } \mathrm{T} \text { output } 65^{\circ} \mathrm{C}\right) \\
& t_{\text {heating }}=0.33 \mathrm{~h}(20 \mathrm{~min})
\end{aligned}
$$


Table S8: Physical parameters used in the modelling. OW= Organic waste, VFW = Vegetable Food Waste, $\mathrm{MW}=$ Mixed waste (without organic source separation), RW = Residual Waste (with organic source separation), $\mathrm{hh}=$ households, $\mathrm{CP}=$ Collection point, $\mathrm{AUR}=$ Annual Usage Rate, $\mathrm{AD}=$ Anaerobic Digestion, $\mathrm{H}=$ Hauling, wi=waste incinerated

\begin{tabular}{|c|c|c|c|c|c|c|c|c|c|}
\hline & & \multicolumn{4}{|c|}{ Single Family Housing } & \multicolumn{4}{|c|}{ Multi-Family Housing } \\
\hline & & $\mathrm{IN}$ & $\mathrm{CD}$ & $\mathrm{AF}$ & PR & IN & $\mathrm{CD}$ & $\mathrm{AF}$ & PR \\
\hline \multirow{2}{*}{ Source Separation $(\%)$} & OW & & 75 & & & & 50 & & \\
\hline & VFW & & & 60 & & & & 40 & \\
\hline \multirow{2}{*}{$\begin{array}{l}\text { Waste Density } \\
\left(\mathrm{kg} \mathrm{m}^{-3}\right)\end{array}$} & MW \& RW & 160 & 120 & 120 & 160 & 160 & 120 & 120 & 160 \\
\hline & OW \& VFW & & 300 & 300 & & & 300 & 300 & \\
\hline \multirow{2}{*}{$\begin{array}{l}\text { Bags } \\
\left(\text { bag } \mathrm{y}^{-1}\right)\end{array}$} & MW \& RW & 82 & 27 & 42 & 37 & 56 & 37 & 46 & \\
\hline & OW \& VFW & & 52 & 52 & & & 52 & 52 & \\
\hline \multirow{2}{*}{$\begin{array}{l}\text { Volume container } \\
\text { (1) }\end{array}$} & MW \& RW & 140 & 140 & 140 & 140 & 660 & 660 & 660 & 660 \\
\hline & OW \& VFW & & 140 & 140 & & & 400 & 400 & \\
\hline \multirow{2}{*}{$\begin{array}{l}\text { HC } \\
\left(\text { hh container }^{-1}\right)\end{array}$} & MW \& RW & 1 & 1 & 1 & 1 & 7 & 7 & 7 & 7 \\
\hline & OW \& VFW & & 1 & 1 & 1 & & 14 & 25 & \\
\hline \multirow{2}{*}{$\begin{array}{l}\text { Coll. frequency } \\
\left(\text { times } \mathrm{y}^{-1} \text { ) }\right.\end{array}$} & MW \& RW & 52 & 52 & 52 & 52 & 52 & 52 & 52 & 52 \\
\hline & OW \& VFW & & 52 & 52 & & & 52 & 52 & \\
\hline \multirow[t]{2}{*}{ Container $\mathrm{CP}^{-1}$} & MW \& RW & 1 & 1 & 1 & 1 & 7 & 7 & 7 & 7 \\
\hline & OW \& VFW & & 1 & 1 & & & 3 & 2 & \\
\hline Time $\mathrm{CP}^{-1}(\min )$ & & \multicolumn{4}{|c|}{0.3} & \multicolumn{4}{|c|}{5} \\
\hline \multirow{3}{*}{$\begin{array}{l}\text { Distances } \\
(\mathrm{km})\end{array}$} & Between stops & \multicolumn{4}{|c|}{0.02} & \multicolumn{4}{|c|}{0.3} \\
\hline & H. MW\&RW & \multicolumn{4}{|c|}{20} & \multicolumn{4}{|c|}{20} \\
\hline & H. OW\&VFW & \multicolumn{4}{|c|}{40} & \multicolumn{4}{|c|}{40} \\
\hline $\mathrm{LHV}\left(\mathrm{GJ} \mathrm{t}^{-1}\right)$ & MW \& RW & 3.56 & 3.56 & 5.52 & 3.00 & 3.91 & 3.91 & 4.89 & 3.22 \\
\hline AUR $\left(1000 \mathrm{t} \mathrm{y}^{-1}\right)$ & & 775 & 706 & 500 & 920 & 706 & 706 & 564 & 857 \\
\hline \multirow[t]{2}{*}{ Ash “( $\mathrm{kg} \mathrm{Mg} \mathrm{wi-1})$} & Bottom Ash & 14.5 & 14.4 & 20.8 & 12.6 & 15.5 & 15.5 & 18.3 & 13.1 \\
\hline & Fly Ash & 2.1 & 2.1 & 3.0 & 1.8 & 2.2 & 2.2 & 2.6 & 1.9 \\
\hline AD plant subsidy & (\% Capital cost) & & 20 & & & & 20 & & \\
\hline Electricity Subsidy & $\left(€ \mathrm{kWh}^{-1}\right)$ & & 0.4 & & & & 0.4 & & \\
\hline
\end{tabular}


Table S9: Inventory of the items included in the income effect from Ecoinvent version 2.2. in $\mathrm{kg}$ of emission or resource per $€ 2003$ of each consumption item. Items 1 to 9 correspond to the categories stated in Table S4. To convert this inventory to $€ 2013$ we used an inflation rate of $22 \%$ as reported by ${ }^{69}$ for the Eurozone.

\begin{tabular}{|c|c|c|c|c|c|c|c|c|c|c|c|}
\hline Inventory per $€$ of consumption item & & & Item 1 & Item 2 & Item 3 & Item 4 & Item 5 & Item 6 & Item 7 & Item 8 & Item 9 \\
\hline Aluminium & Raw & $\mathrm{kg}$ & $1 \mathrm{E}-03$ & $2 \mathrm{E}-03$ & $4 \mathrm{E}-04$ & $5 \mathrm{E}-04$ & 9E-04 & $8 \mathrm{E}-04$ & $1 \mathrm{E}-03$ & 7E-04 & $5 \mathrm{E}-05$ \\
\hline Ammonia & Air & $\mathrm{kg}$ & $2 \mathrm{E}-04$ & $4 \mathrm{E}-05$ & $3 \mathrm{E}-05$ & $5 \mathrm{E}-05$ & $6 \mathrm{E}-05$ & $1 \mathrm{E}-04$ & $2 \mathrm{E}-04$ & $1 \mathrm{E}-03$ & 4E-06 \\
\hline Carbon dioxide, biogenic & Air & $\mathrm{kg}$ & $1 \mathrm{E}-01$ & $3 \mathrm{E}-02$ & $3 \mathrm{E}-02$ & $3 \mathrm{E}-02$ & $1 \mathrm{E}-01$ & $8 \mathrm{E}-01$ & $8 \mathrm{E}-02$ & 7E-01 & $2 \mathrm{E}-03$ \\
\hline Carbon dioxide, fossil & Air & $\mathrm{kg}$ & $1 \mathrm{E}+00$ & $1 \mathrm{E}+00$ & $3 \mathrm{E}-01$ & $3 \mathrm{E}-01$ & $8 \mathrm{E}-01$ & $3 \mathrm{E}+00$ & $7 \mathrm{E}-01$ & $8 \mathrm{E}-01$ & $3 \mathrm{E}-02$ \\
\hline Carbon dioxide, in air & Raw & $\mathrm{kg}$ & 7E-02 & $1 \mathrm{E}-02$ & $1 \mathrm{E}-02$ & $2 \mathrm{E}-02$ & $5 \mathrm{E}-02$ & 2E-01 & $7 \mathrm{E}-02$ & 4E-01 & $1 \mathrm{E}-03$ \\
\hline Carbon monoxide & Air & $\mathrm{kg}$ & 4E-03 & $1 \mathrm{E}-02$ & $1 \mathrm{E}-03$ & $2 \mathrm{E}-03$ & $3 \mathrm{E}-03$ & $1 \mathrm{E}-02$ & $1 \mathrm{E}-02$ & $6 \mathrm{E}-03$ & $2 \mathrm{E}-04$ \\
\hline Coal, hard & Raw & $\mathrm{kg}$ & 2E-01 & 9E-02 & $5 \mathrm{E}-02$ & $5 \mathrm{E}-02$ & $1 \mathrm{E}-01$ & $5 \mathrm{E}-01$ & $1 \mathrm{E}-01$ & $1 \mathrm{E}-01$ & $5 \mathrm{E}-03$ \\
\hline Copper & Raw & $\mathrm{kg}$ & 2E-04 & 4E-04 & $8 \mathrm{E}-05$ & $2 \mathrm{E}-04$ & $3 \mathrm{E}-04$ & $2 \mathrm{E}-04$ & $2 \mathrm{E}-04$ & $2 \mathrm{E}-04$ & $1 \mathrm{E}-05$ \\
\hline Dinitrogen monoxide & Air & $\mathrm{kg}$ & $2 \mathrm{E}-04$ & 9E-05 & $4 \mathrm{E}-05$ & 9E-05 & 9E-05 & 2E-04 & $3 \mathrm{E}-04$ & 9E-04 & $5 \mathrm{E}-06$ \\
\hline Gas, natural & Raw & $\mathrm{kg}$ & 9E-02 & $1 \mathrm{E}-01$ & $2 \mathrm{E}-02$ & $3 \mathrm{E}-02$ & $8 \mathrm{E}-02$ & $3 \mathrm{E}-01$ & 7E-02 & $7 \mathrm{E}-02$ & $2 \mathrm{E}-03$ \\
\hline Iron & Raw & $\mathrm{kg}$ & 7E-03 & 1E-02 & $3 E-03$ & $3 \mathrm{E}-03$ & $8 \mathrm{E}-03$ & $8 \mathrm{E}-03$ & $6 \mathrm{E}-03$ & 7E-03 & $5 \mathrm{E}-04$ \\
\hline Lead & Raw & $\mathrm{kg}$ & $2 \mathrm{E}-06$ & $2 \mathrm{E}-06$ & $8 \mathrm{E}-07$ & $2 \mathrm{E}-06$ & $2 \mathrm{E}-06$ & $2 \mathrm{E}-06$ & $2 \mathrm{E}-06$ & $2 \mathrm{E}-06$ & $1 \mathrm{E}-07$ \\
\hline Methane & Air & $\mathrm{kg}$ & $3 E-03$ & 1E-03 & 7E-04 & $8 \mathrm{E}-04$ & $2 \mathrm{E}-03$ & 7E-03 & $3 \mathrm{E}-03$ & $1 \mathrm{E}-02$ & $6 \mathrm{E}-05$ \\
\hline Nickel & Raw & $\mathrm{kg}$ & 9E-04 & $1 \mathrm{E}-03$ & $4 \mathrm{E}-04$ & $8 \mathrm{E}-04$ & $8 \mathrm{E}-04$ & 9E-04 & $8 \mathrm{E}-04$ & $8 \mathrm{E}-04$ & $7 \mathrm{E}-05$ \\
\hline Nitrogen dioxide & Air & $\mathrm{kg}$ & $2 \mathrm{E}-03$ & 5E-03 & $7 \mathrm{E}-04$ & $8 \mathrm{E}-04$ & $2 \mathrm{E}-03$ & $3 \mathrm{E}-03$ & $2 \mathrm{E}-03$ & $2 \mathrm{E}-03$ & 9E-05 \\
\hline NMVOC, unspecified origin & Air & $\mathrm{kg}$ & $1 \mathrm{E}-03$ & $3 \mathrm{E}-03$ & $3 \mathrm{E}-04$ & $5 \mathrm{E}-04$ & $8 \mathrm{E}-04$ & 2E-03 & $2 \mathrm{E}-03$ & $2 \mathrm{E}-03$ & $4 \mathrm{E}-05$ \\
\hline Oil, crude & Raw & $\mathrm{kg}$ & $1 \mathrm{E}-01$ & 2E-01 & 4E-02 & $5 \mathrm{E}-02$ & $1 \mathrm{E}-01$ & 4E-01 & $1 \mathrm{E}-01$ & $1 \mathrm{E}-01$ & 4E-03 \\
\hline Other minerals (extracted for use) & Raw & $\mathrm{kg}$ & $7 \mathrm{E}-02$ & $3 \mathrm{E}-02$ & $1 \mathrm{E}-02$ & $5 \mathrm{E}-02$ & $5 \mathrm{E}-02$ & $6 \mathrm{E}-02$ & 9E-02 & $1 \mathrm{E}-01$ & $2 \mathrm{E}-03$ \\
\hline Other minerals (related unused extraction) & Raw & $\mathrm{kg}$ & $1 \mathrm{E}-02$ & 2E-02 & $5 \mathrm{E}-03$ & $8 \mathrm{E}-03$ & $1 \mathrm{E}-02$ & $1 \mathrm{E}-02$ & $1 \mathrm{E}-02$ & $1 \mathrm{E}-02$ & $8 \mathrm{E}-04$ \\
\hline Sand and clay & Raw & $\mathrm{kg}$ & $4 \mathrm{E}-01$ & 4E-01 & $2 \mathrm{E}-01$ & $2 \mathrm{E}-01$ & 9E-01 & 4E-01 & $5 \mathrm{E}-01$ & 4E-01 & $5 \mathrm{E}-02$ \\
\hline Sulfur dioxide & Air & $\mathrm{kg}$ & $3 \mathrm{E}-03$ & 2E-03 & 7E-04 & $8 \mathrm{E}-04$ & 2E-03 & 5E-03 & 2E-03 & $2 \mathrm{E}-03$ & $7 \mathrm{E}-05$ \\
\hline Zinc & Raw & $\mathrm{kg}$ & $6 \mathrm{E}-06$ & 7E-06 & $3 \mathrm{E}-06$ & $5 \mathrm{E}-06$ & 5E-06 & 6E-06 & $5 \mathrm{E}-06$ & $5 \mathrm{E}-06$ & 5E-07 \\
\hline
\end{tabular}




\section{Upstream food commodities - Factor prices \& Ecoinvent names}

Table S10: Factor prices from ${ }^{3}$ and names of the processes used from Ecoinvent.

\begin{tabular}{|c|c|c|c|}
\hline \multirow{2}{*}{$\begin{array}{l}\text { Food } \\
\text { Commodity }\end{array}$} & Price & \multicolumn{2}{|l|}{ Ecoinvent } \\
\hline & $\mathrm{DKK} / \mathrm{kg}$ & Process name & Project name \\
\hline Beef meat & 92.38 & Beef (farm type 23) & LCA food DK \\
\hline Butter & 66.72 & Spreadable (Kærgården) & \\
\hline Cheese & 84.58 & Cheese & \\
\hline Chicken meat & 96.58 & Chicken & \\
\hline Eggs & 38.27 & Egg & \\
\hline Fish & 147.43 & Trout (standard), from trout pond farm & \\
\hline Milk & 6.90 & Milk, conventional, from farm, without quotas & \\
\hline Pork meat & 83.45 & Pork, from farm & \\
\hline Yoghurt & 15.52 & Assumed same impact as milk per kilogram ${ }^{70}$ & \\
\hline Bread & 30.63 & Bread, wheat, conventional, fresh & \\
\hline Pasta (øko) & 30.81 & $\begin{array}{l}\text { Assumed } 1,33 \mathrm{t} \text { durum wheat } \mathrm{x} 1 \mathrm{~kg} \text { pasta } \\
\text { Flour, wheat, conventional }\end{array}$ & \\
\hline Apple & 15.43 & Apple $\{$ GLO $\} \mid$ market for $\mid$ Conseq, $U$ & Ecoinvent 3 - \\
\hline Banana & 14.34 & Banana $\{\mathrm{GLO}\} \mid$ market for $\mid$ Conseq, $\mathrm{U}$ & consequential - \\
\hline Cabbage & 6.28 & Cabbage white $\{$ GLO $\} \mid$ market for $\mid$ Conseq, $U$ & unit \\
\hline Carrots & 8.27 & Carrot $\{$ GLO $\} \mid 335$ production $\mid$ Conseq, $U$ & \\
\hline Citrus & 11.92 & Citrus $\{\mathrm{GLO}\} \mid$ production $\mid$ Conseq, $\mathrm{U}$ & \\
\hline Grapes & 34.91 & Grape $\{\mathrm{GLO}\} \mid$ production $\mid$ Conseq, $\mathrm{U}$ & \\
\hline Kiwi & 14.85 & Kiwi $\{$ GLO $\} \mid$ production | Conseq, $\mathrm{U}$ & \\
\hline Potatoes & 9.34 & Potato $\{\mathrm{GLO}\} \mid$ production $\mid$ Conseq, $\mathrm{U}$ & \\
\hline Rice & 26.85 & Rice $\{$ GLO $\} \mid$ production $\mid$ Conseq, $U$ & \\
\hline Tomatoes & 26.35 & Tomato $\{\mathrm{GLO}\} \mid$ production | Conseq, $\mathrm{U}$ & \\
\hline Maize & 1.45 & Maize grain $\{$ GLO $\} \mid$ market for $\mid$ Conseq, $U$ & \\
\hline
\end{tabular}




\section{Accounting prices of emissions}

The shadow prices of emissions (also so-called accounting prices) should represent the "marginal damage cost" of an emission. Due to the difficulty of this calculation other approaches are applied such as: 1) National reduction costs, 2) Marginal reduction costs of the emission and 3) Tax $=$ highest cost at which a reduction will take place. When the tax is applied in the welfare economic assessment, its real value has to be multiplied by the Net-Tax-Factor. Data available depends on the emission, here we used values reported in Table S11:

Table S11: Accounting prices used in the investigation. $\mathrm{CF}=$ Characterization factor

\begin{tabular}{|c|c|c|}
\hline Emission & Value used & Reference \\
\hline $\mathrm{CO}_{2}$ & Allowance price for 2014 , i.e. $155.4 \mathrm{DKK} /$ ton ( 2009 prices), $21 € / \mathrm{CO}_{2}$. & 72 \\
\hline $\mathrm{CH}_{4}$ & CO2- Allowance price $* 25$ (CF for global warming) & 73 \\
\hline $\mathrm{N}_{2} \mathrm{O}$ & CO2- Allowance price $* 298$ (CF for global warming) & 73 \\
\hline $\mathrm{PM}_{2.5}$ & $\begin{array}{l}\text { Damage cost from stationary installation: } \\
105 \mathrm{DKK} / \mathrm{kg} \text { in urban areas. }(14,189 € / \text { ton })\end{array}$ & 72 \\
\hline $\mathrm{NO}_{\mathrm{x}}$ & $\begin{array}{l}\text { Damage cost from stationary installation: } \\
46 \mathrm{DKK} / \mathrm{kg} \text { in rural and urban areas. }(6,216 € / \mathrm{t})\end{array}$ & 72 \\
\hline $\mathrm{SO}_{2} / \mathrm{SO}_{4}$ & $\begin{array}{l}\text { Damage cost from stationary installation: } \\
89 \mathrm{DKK} / \mathrm{kg} \text { in urban areas }(12,027 € / \mathrm{t})\end{array}$ & 72 \\
\hline $\mathrm{CO}$ & Urban 23.1 DKK/ton $(3.12 € /$ ton $)$ & 74 \\
\hline $\mathrm{HC}$ & Urban 2.79 DKK/kg (377 €/ton) & 74 \\
\hline $\mathrm{Hg}$ & Urban: $1,906 \mathrm{DKK} / \mathrm{kg}(257,567 € /$ ton $)$ & 75 \\
\hline $\mathrm{Pb}$ & Urban: $10,406 \mathrm{DKK} / \mathrm{kg}(1,406,216 € /$ ton $)$ & 75 \\
\hline Dioxins & $2,078,729 \mathrm{DKK} / \mathrm{kg}(280,909 € /$ ton $)$ & 76 \\
\hline
\end{tabular}




\section{Detailed Results}

\section{A. Environmental LCC: Financial Assessment}

Table S12 summarizes the results of the financial assessment in million $€$ per functional unit (FU). It includes the costs incurred by the 6 actors affected by the system (i.e., WMS, energy sector, food industry, agriculture, general industry affected by income effects and the State). The household expenses are assumed to be the sum of the expenses incurred by the abovementioned sectors minus the state costs. The subtraction relates to the fact that some costs for the households are benefits for the state, e.g. taxes paid to the State are accounted as benefits for the State (negative value), and as costs for the household (positive value).

Results are separated are shown with and without indirect effects, i.e. Direct effects and Total Effects. The only difference between these results is on the expenses of the income effect-industry as budget costs and transfers.

If only direct effects are included, the households' expenses differ between scenarios, and some money flows are not considered in the system boundaries. The households expenses of Sc-CD and Sc-AF are 34 and $41 \mathrm{M} €$ respectively higher than Sc-IN (Baseline), and these money flows are incorporated within the system boundaries without any consequence. In contrary, in Sc-PR some money flows are taken out of the economy without consequences, the households expenses of ScPR are $1226 \mathrm{M} €$ lower than Sc-IN (1255-29).

When direct and indirect effects are accounted (total effects), the households expenses are equal for all the scenarios and correspond to $1255 \mathrm{M} €$. For the financial assessment, it does not matter which is the marginal consumption of the case study because it has been aggregated into a single actor (Income effect- industry). 
Table S12: Financial Assessment of the four scenarios assessed in million $€(M €)$ per functional unit (FU) including only direct effects (direct effects) and including total effects.

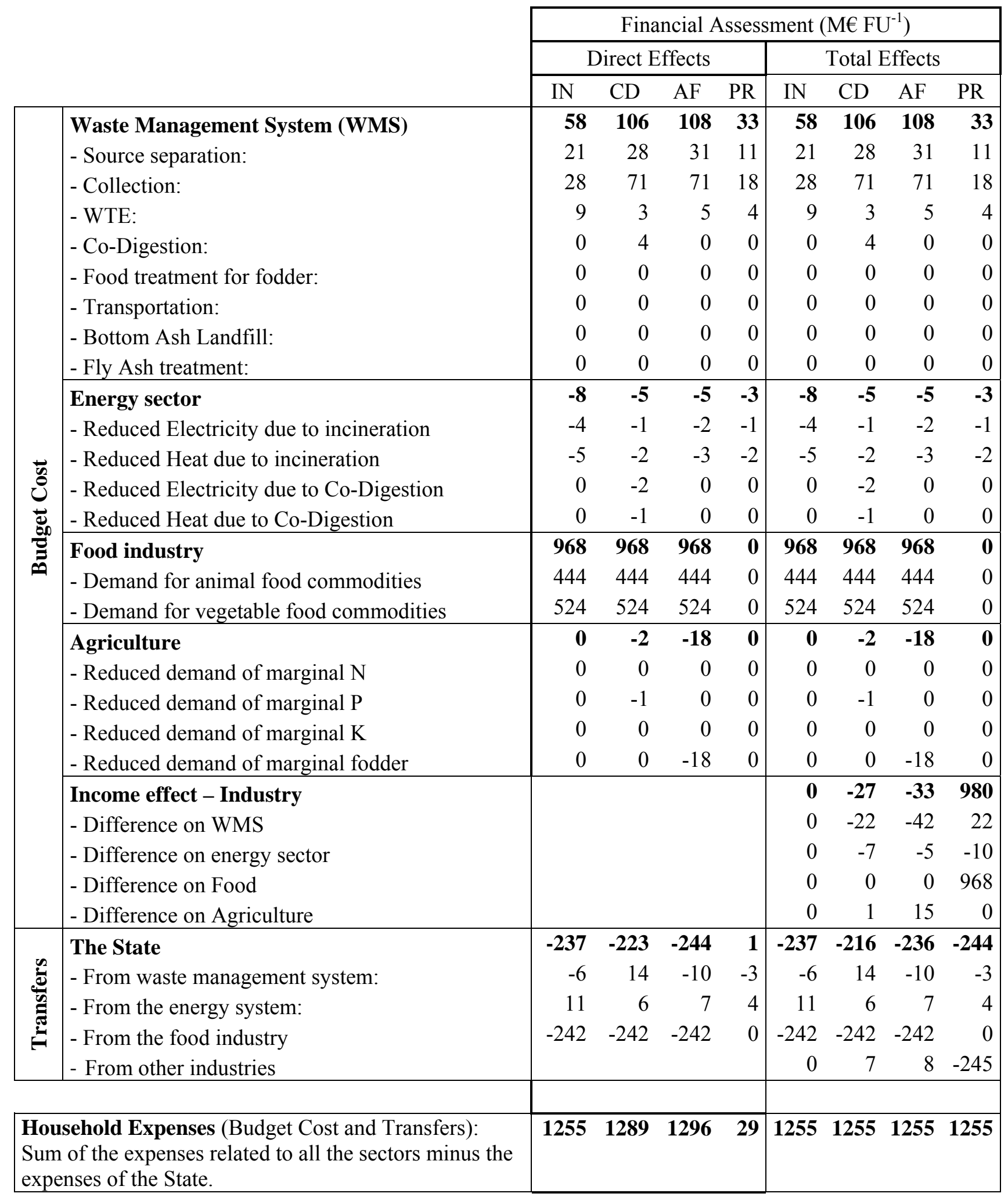




\section{B. Environmental LCC: Environmental part (LCA)}

Table S13 summarizes the LCA results of the total effects (direct and indirect effects). The results including only direct effects, represented in Figure 2A (II), can be estimated by excluding the impacts of "income effects" and "iLUC" from Table S13.

The impacts related to "income effects" shown in Table S13 results from the product of the impact associated with one $€ 2015$ shown in Table S14 times the budget costs associated with income effects in each scenario from Table S12 (i.e. $0 \mathrm{M} €$ in Sc-IN, -27 M€ in Sc-CD, -33 M€ in Sc-AF and $980 \mathrm{M} €$ in Sc-PR). In addition, Table S13 show as well the variation of the net results in the extreme cases of income effects (using the maximum and minimum impacts per $€ 2015$ shown in Table S14. The iLUC impacts are related to the food industry and the agriculture (marginal fodder), but shown separately to be able to evaluate the importance of this indirect effect.

Table S13: LCA results as characterized impacts per functional unit. GW= Global Warming, $\mathrm{POF}=$ Photochemical Ozone Formation.

\begin{tabular}{|c|c|c|c|c|c|c|c|c|}
\hline & \multicolumn{4}{|c|}{ GW (kg CO2) } & \multicolumn{4}{|c|}{ POF (kg NMVOC) } \\
\hline & IN & $\mathrm{CD}$ & $\mathrm{AF}$ & PR & IN & $\mathrm{CD}$ & $\mathrm{AF}$ & PR \\
\hline WMS & $1 E+07$ & $4 \mathrm{E}+07$ & $5 E+07$ & $8 E+06$ & $4 \mathrm{E}+05$ & $3 E+05$ & $2 E+05$ & $2 E+05$ \\
\hline - Source separation: & $4 \mathrm{E}+06$ & $4 \mathrm{E}+06$ & $5 \mathrm{E}+06$ & $4 \mathrm{E}+06$ & $8 \mathrm{E}+03$ & $9 \mathrm{E}+03$ & $1 \mathrm{E}+04$ & $8 \mathrm{E}+03$ \\
\hline - Collection: & $4 \mathrm{E}+06$ & $4 \mathrm{E}+06$ & $4 \mathrm{E}+06$ & $2 \mathrm{E}+06$ & $4 \mathrm{E}+03$ & $4 \mathrm{E}+03$ & $4 \mathrm{E}+03$ & $2 \mathrm{E}+03$ \\
\hline - WTE: & $3 \mathrm{E}+06$ & $1 \mathrm{E}+06$ & $2 \mathrm{E}+06$ & $9 \mathrm{E}+05$ & $4 \mathrm{E}+05$ & $2 \mathrm{E}+05$ & $2 \mathrm{E}+05$ & $2 \mathrm{E}+05$ \\
\hline - Co-Digestion: & $0 \mathrm{E}+00$ & $3 \mathrm{E}+07$ & $0 \mathrm{E}+00$ & $0 \mathrm{E}+00$ & $0 \mathrm{E}+00$ & $6 \mathrm{E}+04$ & $0 \mathrm{E}+00$ & $0 \mathrm{E}+00$ \\
\hline - Food treatment for fodder: & $0 \mathrm{E}+00$ & $0 \mathrm{E}+00$ & $4 \mathrm{E}+07$ & $0 \mathrm{E}+00$ & $0 \mathrm{E}+00$ & $0 \mathrm{E}+00$ & $3 \mathrm{E}+04$ & $0 \mathrm{E}+00$ \\
\hline - Transportation: & $4 \mathrm{E}+06$ & $4 \mathrm{E}+06$ & $4 \mathrm{E}+06$ & $2 \mathrm{E}+06$ & $4 \mathrm{E}+03$ & $4 \mathrm{E}+03$ & $4 \mathrm{E}+03$ & $2 \mathrm{E}+03$ \\
\hline - Bottom Ash Landfill: & $4 \mathrm{E}+04$ & $2 \mathrm{E}+04$ & $3 \mathrm{E}+04$ & $2 \mathrm{E}+04$ & $9 \mathrm{E}+01$ & $5 \mathrm{E}+01$ & $6 \mathrm{E}+01$ & $4 \mathrm{E}+01$ \\
\hline - Fly Ash treatment: & $1 \mathrm{E}+04$ & $7 \mathrm{E}+03$ & $8 \mathrm{E}+03$ & $5 \mathrm{E}+03$ & $3 \mathrm{E}+01$ & $1 \mathrm{E}+01$ & $2 \mathrm{E}+01$ & $1 \mathrm{E}+01$ \\
\hline Marginal Energy & $-1 E+08$ & $-1 E+08$ & $-1 E+08$ & $-6 \mathrm{E}+07$ & $-2 E+05$ & $-2 \mathrm{E}+05$ & $-1 E+05$ & $-9 \mathrm{E}+04$ \\
\hline Food industry & $3 \mathrm{E}+08$ & $3 \mathrm{E}+08$ & $3 \mathrm{E}+08$ & $0 \mathrm{E}+00$ & $5 \mathrm{E}+05$ & $5 \mathrm{E}+05$ & $5 \mathrm{E}+05$ & $0 \mathrm{E}+00$ \\
\hline - Demand for animal food & $2 \mathrm{E}+08$ & $2 \mathrm{E}+08$ & $2 \mathrm{E}+08$ & & $3 \mathrm{E}+05$ & $3 \mathrm{E}+05$ & $3 \mathrm{E}+05$ & \\
\hline - Demand for vegetable food & $1 \mathrm{E}+08$ & $1 \mathrm{E}+08$ & $1 \mathrm{E}+08$ & & $3 \mathrm{E}+05$ & $3 \mathrm{E}+05$ & $3 \mathrm{E}+05$ & \\
\hline Agriculture & $0 \mathrm{E}+\mathbf{0 0}$ & $-5 E+06$ & $-3 E+07$ & $\mathbf{0 E}+00$ & OE+00 & $-2 E+04$ & $-1 E+05$ & $\mathbf{0 E}+00$ \\
\hline - Reduced demand of PK & & $-5 \mathrm{E}+06$ & & & & $-2 \mathrm{E}+04$ & & \\
\hline - Reduced demand of maize & & & $-3 \mathrm{E}+07$ & & & & $-1 \mathrm{E}+05$ & \\
\hline Income effect & $0 \mathrm{E}+00$ & $-2 E+07$ & $-3 E+07$ & $8 \mathrm{E}+08$ & $0 \mathrm{E}+00$ & $-4 E+03$ & $-5 E+03$ & $2 \mathrm{E}+05$ \\
\hline iLUC & $1 \mathrm{E}+08$ & $1 E+08$ & $7 E+07$ & $0 \mathrm{E}+00$ & $3 E+05$ & $3 E+05$ & $2 E+05$ & $0 \mathrm{E}+00$ \\
\hline - AFW & $7 \mathrm{E}+07$ & $7 \mathrm{E}+07$ & $7 \mathrm{E}+07$ & & $2 \mathrm{E}+05$ & $2 \mathrm{E}+05$ & $2 \mathrm{E}+05$ & \\
\hline - VFW & $3 \mathrm{E}+07$ & $3 \mathrm{E}+07$ & $3 \mathrm{E}+07$ & & $9 \mathrm{E}+04$ & $9 \mathrm{E}+04$ & $9 \mathrm{E}+04$ & \\
\hline - Maize & & & $-3 E+07$ & & & & $-9 \mathrm{E}+04$ & \\
\hline Net Impact: & $3 \mathrm{E}+08$ & $\underline{3 \mathrm{E}+08}$ & $\underline{3 \mathrm{E}+08}$ & $\underline{7 \mathrm{E}+08}$ & $\underline{1 E+06}$ & $\underline{9 \mathrm{E}+05}$ & $\underline{7 E+05}$ & $\underline{3 E+05}$ \\
\hline
\end{tabular}

Results variation due to income effect distribution:

\begin{tabular}{|l|llll|llll|}
\hline Net Impact (MAX) & $3 \mathrm{E}+08$ & $3 \mathrm{E}+08$ & $3 \mathrm{E}+08$ & $2 \mathrm{E}+09$ & $7.2 \mathrm{E}+05$ & $6.1 \mathrm{E}+05$ & $4.8 \mathrm{E}+05$ & $4.8 \mathrm{E}+05$ \\
\hline Net Impact (MIN) & $3 \mathrm{E}+08$ & $3 \mathrm{E}+08$ & $3 \mathrm{E}+08$ & $1 \mathrm{E}+09$ & $7.2 \mathrm{E}+05$ & $6.1 \mathrm{E}+05$ & $4.8 \mathrm{E}+05$ & $3.6 \mathrm{E}+05$ \\
\hline
\end{tabular}


Continuation Table S13. RD $\mathrm{f}=$ fossil Resource Depletion, $\mathrm{RD} \mathrm{m}=$ mineral Resource Depletion.

\begin{tabular}{|c|c|c|c|c|c|c|c|c|}
\hline & \multicolumn{4}{|c|}{$\mathrm{RD} \mathrm{f}(\mathrm{MJ})$} & \multicolumn{4}{|c|}{ RD m (kg Sb eq) } \\
\hline & IN & $\mathrm{CD}$ & $\mathrm{AF}$ & PR & IN & $\mathrm{CD}$ & $\mathrm{AF}$ & PR \\
\hline WMS & $1 \mathrm{E}+09$ & $2 E+09$ & $1 \mathrm{E}+09$ & $5 E+08$ & $2 \mathrm{E}+00$ & $2 \mathrm{E}+00$ & $3 E+00$ & $2 \mathrm{E}+00$ \\
\hline - Source separation: & $0 \mathrm{E}+00$ & $0 \mathrm{E}+00$ & $0 \mathrm{E}+00$ & $0 \mathrm{E}+00$ & $2 \mathrm{E}+00$ & $3 \mathrm{E}+00$ & $3 \mathrm{E}+00$ & $2 \mathrm{E}+00$ \\
\hline - Collection: & $5 \mathrm{E}+08$ & $5 \mathrm{E}+08$ & $5 \mathrm{E}+08$ & $2 \mathrm{E}+08$ & $4 \mathrm{E}-05$ & $4 \mathrm{E}-05$ & $4 \mathrm{E}-05$ & $2 \mathrm{E}-05$ \\
\hline - WTE: & $1 \mathrm{E}+07$ & $5 \mathrm{E}+06$ & $5 \mathrm{E}+06$ & $5 \mathrm{E}+06$ & $3 \mathrm{E}-04$ & $1 \mathrm{E}-04$ & $1 \mathrm{E}-04$ & $1 \mathrm{E}-04$ \\
\hline - Co-Digestion: & $0 \mathrm{E}+00$ & $5 \mathrm{E}+08$ & $0 \mathrm{E}+00$ & $0 \mathrm{E}+00$ & $0 \mathrm{E}+00$ & $5 \mathrm{E}-05$ & $0 \mathrm{E}+00$ & $0 \mathrm{E}+00$ \\
\hline - Food treatment for fodder: & $0 \mathrm{E}+00$ & $0 \mathrm{E}+00$ & $4 \mathrm{E}+08$ & $0 \mathrm{E}+00$ & $0 \mathrm{E}+00$ & $0 \mathrm{E}+00$ & $5 \mathrm{E}-05$ & $0 \mathrm{E}+00$ \\
\hline - Transportation: & $5 \mathrm{E}+08$ & $5 \mathrm{E}+08$ & $5 \mathrm{E}+08$ & $2 \mathrm{E}+08$ & $3 \mathrm{E}-04$ & $1 \mathrm{E}-04$ & $2 \mathrm{E}-04$ & $1 \mathrm{E}-04$ \\
\hline - Bottom Ash Landfill: & $4 \mathrm{E}+06$ & $2 \mathrm{E}+06$ & $3 \mathrm{E}+06$ & $2 \mathrm{E}+06$ & $-3 \mathrm{E}-01$ & $-1 \mathrm{E}-01$ & $-2 \mathrm{E}-01$ & $-1 \mathrm{E}-01$ \\
\hline - Fly Ash treatment: & $4 \mathrm{E}+05$ & $2 \mathrm{E}+05$ & $3 \mathrm{E}+05$ & $2 \mathrm{E}+05$ & 4E-08 & $2 \mathrm{E}-08$ & $2 \mathrm{E}-08$ & $2 \mathrm{E}-08$ \\
\hline Marginal Energy & $-1 E+09$ & $-1 E+09$ & $-8 \mathrm{E}+08$ & $-5 E+08$ & $-1 E-04$ & -1E-04 & -9E-05 & $-5 E-05$ \\
\hline Food industry & $1 \mathrm{E}+09$ & $1 E+09$ & $1 E+09$ & $0 \mathrm{E}+00$ & $5 E+02$ & $5 \mathrm{E}+02$ & $5 E+02$ & $\mathbf{0 E}+00$ \\
\hline - Demand for animal food & $4 \mathrm{E}+08$ & $4 \mathrm{E}+08$ & $4 \mathrm{E}+08$ & & $2 \mathrm{E}+02$ & $2 \mathrm{E}+02$ & $2 \mathrm{E}+02$ & \\
\hline - Demand for vegetable food & $1 \mathrm{E}+09$ & $1 \mathrm{E}+09$ & $1 \mathrm{E}+09$ & & $2 \mathrm{E}+02$ & $2 \mathrm{E}+02$ & $2 \mathrm{E}+02$ & \\
\hline Agriculture & $0 \mathrm{E}+00$ & $-5 E+07$ & $-2 E+08$ & $0 \mathrm{E}+\mathbf{0 0}$ & $0 \mathrm{E}+00$ & $-6 \mathrm{E}+02$ & $-6 E+01$ & $0 \mathrm{E}+00$ \\
\hline - Reduced demand of PK & & $-5 \mathrm{E}+07$ & & & & $-6 \mathrm{E}+02$ & & \\
\hline - Reduced demand of maize & & & $-2 \mathrm{E}+08$ & & & & $-6 \mathrm{E}+01$ & \\
\hline Income effect & $0 \mathrm{E}+00$ & $-3 E+08$ & $-4 E+08$ & $1 \mathrm{E}+10$ & $0 \mathrm{E}+00$ & $-1 \mathrm{E}+02$ & $-1 \mathrm{E}+02$ & $3 E+03$ \\
\hline iLUC & $2 E+08$ & $2 E+08$ & $2 E+08$ & $0 \mathrm{E}+00$ & $2 E+03$ & $2 E+03$ & $1 E+03$ & $0 \mathrm{E}+00$ \\
\hline - AFW & $1 \mathrm{E}+08$ & $1 \mathrm{E}+08$ & $1 \mathrm{E}+08$ & & $1 \mathrm{E}+03$ & $1 \mathrm{E}+03$ & $1 \mathrm{E}+03$ & \\
\hline - VFW & $7 \mathrm{E}+07$ & $7 \mathrm{E}+07$ & $7 \mathrm{E}+07$ & & $6 \mathrm{E}+02$ & $6 \mathrm{E}+02$ & $6 \mathrm{E}+02$ & \\
\hline - Maize & & & $-7 \mathrm{E}+07$ & & & & $-6 \mathrm{E}+02$ & \\
\hline Net Impact: & $\underline{1 \mathrm{E}+09}$ & $\underline{2 \mathrm{E}+09}$ & $\underline{\underline{2 E}+09}$ & $\underline{\underline{1 E+10}}$ & $\underline{2 \mathrm{E}+03}$ & $\underline{2 \mathrm{E}+03}$ & $\underline{2 \mathrm{E}+03}$ & $\underline{3 E+03}$ \\
\hline
\end{tabular}

\begin{tabular}{|l|llll|llll|}
\hline Results variation due to income effect distribution: \\
\hline Net Impact (MAX) & $1 \mathrm{E}+09$ & $9 \mathrm{E}+08$ & $8 \mathrm{E}+08$ & $3 \mathrm{E}+10$ & $2 \mathrm{E}+03$ & $2 \mathrm{E}+03$ & $2 \mathrm{E}+03$ & $5 \mathrm{E}+03$ \\
\hline Net Impact (MIN) & $1 \mathrm{E}+09$ & $1 \mathrm{E}+09$ & $1 \mathrm{E}+09$ & $2 \mathrm{E}+10$ & $2 \mathrm{E}+03$ & $2 \mathrm{E}+03$ & $2 \mathrm{E}+03$ & $5 \mathrm{E}+03$ \\
\hline
\end{tabular}


Continuation Table S13. $\mathrm{EU} \mathrm{mw}=$ marine water Eutrophication.

\begin{tabular}{|c|c|c|c|c|}
\hline & \multicolumn{4}{|c|}{ EU mw (kg N-Eq) } \\
\hline & IN & $C D$ & $\mathrm{AF}$ & PR \\
\hline WMS & $2 E+05$ & $4 \mathrm{E}+05$ & $9 \mathrm{E}+04$ & $7 E+04$ \\
\hline - Source separation: & $3 \mathrm{E}+03$ & $3 \mathrm{E}+03$ & $4 \mathrm{E}+03$ & $3 \mathrm{E}+03$ \\
\hline - Collection: & $1 \mathrm{E}+03$ & $1 \mathrm{E}+03$ & $1 \mathrm{E}+03$ & $5 \mathrm{E}+02$ \\
\hline - WTE: & $2 \mathrm{E}+05$ & $8 \mathrm{E}+04$ & $7 \mathrm{E}+04$ & $7 \mathrm{E}+04$ \\
\hline - Co-Digestion: & $0 \mathrm{E}+00$ & $3 \mathrm{E}+05$ & $0 \mathrm{E}+00$ & $0 \mathrm{E}+00$ \\
\hline - Food treatment for fodder: & $0 \mathrm{E}+00$ & $0 \mathrm{E}+00$ & $1 \mathrm{E}+04$ & $0 \mathrm{E}+00$ \\
\hline - Transportation: & $1 \mathrm{E}+03$ & $1 \mathrm{E}+03$ & $1 \mathrm{E}+03$ & $6 \mathrm{E}+02$ \\
\hline - Bottom Ash Landfill: & $4 \mathrm{E}+01$ & $2 \mathrm{E}+01$ & $2 \mathrm{E}+01$ & $2 \mathrm{E}+01$ \\
\hline - Fly Ash treatment: & $9 \mathrm{E}+00$ & $4 \mathrm{E}+00$ & $5 \mathrm{E}+00$ & $3 \mathrm{E}+00$ \\
\hline Marginal Energy & $-8 \mathrm{E}+04$ & $-6 E+04$ & $-5 E+04$ & $-3 E+04$ \\
\hline Food industry & $4 \mathrm{E}+06$ & $4 \mathrm{E}+06$ & $4 E+06$ & 0E+00 \\
\hline - Demand for animal food & $3 \mathrm{E}+06$ & $3 \mathrm{E}+06$ & $3 \mathrm{E}+06$ & $0 \mathrm{E}+00$ \\
\hline - Demand for vegetable food & $1 \mathrm{E}+06$ & $1 \mathrm{E}+06$ & $1 \mathrm{E}+06$ & $0 \mathrm{E}+00$ \\
\hline Agriculture & $0 \mathrm{E}+00$ & $-7 E+03$ & $-3 E+05$ & 0E+00 \\
\hline - Reduced demand of PK & $0 \mathrm{E}+00$ & $-7 \mathrm{E}+03$ & $0 \mathrm{E}+00$ & $0 \mathrm{E}+00$ \\
\hline - Reduced demand of maize & $0 \mathrm{E}+00$ & $0 \mathrm{E}+00$ & $-3 \mathrm{E}+05$ & $0 \mathrm{E}+00$ \\
\hline Income effect & $0 \mathrm{E}+00$ & $-4 E+02$ & $-5 E+02$ & $1 \mathrm{E}+04$ \\
\hline iLUC & $9 E+04$ & $9 E+04$ & $6 \mathrm{E}+04$ & 0E+00 \\
\hline - AFW & $6 \mathrm{E}+04$ & $6 \mathrm{E}+04$ & $6 \mathrm{E}+04$ & \\
\hline - VFW & $3 \mathrm{E}+04$ & $3 \mathrm{E}+04$ & $3 \mathrm{E}+04$ & \\
\hline - Maize & & & $-3 \mathrm{E}+04$ & \\
\hline Net Impact: & $\underline{4 \mathrm{E}+06}$ & $\underline{4 \mathrm{E}+06}$ & $\underline{4 \mathrm{E}+06}$ & $\underline{6 \mathrm{E}+04}$ \\
\hline
\end{tabular}

\begin{tabular}{|l|llll|}
\hline \multicolumn{6}{|l|}{ Results variation due to income effect distribution: } \\
\hline Net Impact (MAX) & $4 \mathrm{E}+06$ & $4 \mathrm{E}+06$ & $4 \mathrm{E}+06$ & $1 \mathrm{E}+05$ \\
\hline Net Impact (MIN) & $4 \mathrm{E}+06$ & $4 \mathrm{E}+06$ & $4 \mathrm{E}+06$ & $7 \mathrm{E}+04$ \\
\hline
\end{tabular}


Table S14: Characterized environmental impact associated with the input/output process used in the income effects per $€ 2015$. The impact associated with the marginal consumption of the baseline results by income distribution shown in Table S4 and Figure 1 and these characterized impacts per item. The cells colored in red represent the maximum impact in each category given by a specific item whereas the greens represent the minimum impacts. $\mathrm{GW}=$ Global Warming, POF=Photochemical Ozone Formation, $\mathrm{RD} f=$ fossil Resource Depletion, RD $\mathrm{m}=$ mineral Resource Depletion, EU mw = marine water Eutrophication.

\begin{tabular}{|l|rrrrr|}
\hline & \multicolumn{5}{|c|}{ Characterized impact per $€$ 2015 } \\
\cline { 2 - 6 } Items used in the income effects distribution & $\begin{array}{r}\mathrm{GW} \\
\mathrm{kg} \mathrm{CO} 2\end{array}$ & $\begin{array}{r}\text { POF } \\
\text { kg NMVOC }\end{array}$ & $\begin{array}{r}\text { RD (m) } \\
\mathrm{kg} \mathrm{Sb}\end{array}$ & $\begin{array}{r}\text { RD }(\mathrm{f}) \\
\mathrm{MJ}\end{array}$ & $\begin{array}{r}\mathrm{EU}(\mathrm{m}) \\
\mathrm{kg} \mathrm{N}\end{array}$ \\
\hline 133 Household use, Clothing, EU27 & $8.9 \mathrm{E}-01$ & $2.3 \mathrm{E}-04$ & $3.4 \mathrm{E}-06$ & $1.3 \mathrm{E}+01$ & $1.5 \mathrm{E}-05$ \\
134 Household use, Communication, EU27 & $8.4 \mathrm{E}-01$ & $1.3 \mathrm{E}-04$ & $4.8 \mathrm{E}-06$ & $1.3 \mathrm{E}+01$ & $2.8 \mathrm{E}-06$ \\
135 Household use, Education, EU27 & $2.6 \mathrm{E}-01$ & $5.6 \mathrm{E}-05$ & $1.6 \mathrm{E}-06$ & $3.6 \mathrm{E}+00$ & $2.6 \mathrm{E}-06$ \\
136 Household use, Health care, EU27 & $2.3 \mathrm{E}-01$ & $4.9 \mathrm{E}-05$ & $2.5 \mathrm{E}-06$ & $3.3 \mathrm{E}+00$ & $3.3 \mathrm{E}-06$ \\
137 Household use, Housing, EU27 & $7.4 \mathrm{E}-01$ & $1.5 \mathrm{E}-04$ & $3.4 \mathrm{E}-06$ & $1.1 \mathrm{E}+01$ & $4.9 \mathrm{E}-06$ \\
138 Household use, Hygiene, EU27 & $2.2 \mathrm{E}+00$ & $3.8 \mathrm{E}-04$ & $3.1 \mathrm{E}-06$ & $3.5 \mathrm{E}+01$ & $8.9 \mathrm{E}-06$ \\
139 Household use, Leisure, EU27 & $8.4 \mathrm{E}-01$ & $1.9 \mathrm{E}-04$ & $3.9 \mathrm{E}-06$ & $1.1 \mathrm{E}+01$ & $1.7 \mathrm{E}-05$ \\
140 Household use, Meals, EU27 & $8.9 \mathrm{E}-01$ & $2.0 \mathrm{E}-04$ & $2.4 \mathrm{E}-06$ & $8.5 \mathrm{E}+00$ & $6.7 \mathrm{E}-05$ \\
141 Household use, Security, EU27 & $2.5 \mathrm{E}-01$ & $5.3 \mathrm{E}-05$ & $2.6 \mathrm{E}-06$ & $3.5 \mathrm{E}+00$ & $2.7 \mathrm{E}-06$ \\
\hline Impact of the Marginal Consumption (baseline) & $7.7 \mathrm{E}-01$ & $1.5 \mathrm{E}-04$ & $3.6 \mathrm{E}-06$ & $1.1 \mathrm{E}+01$ & $1.5 \mathrm{E}-05$ \\
\hline
\end{tabular}

\section{Societal LCC}

Table S15 summarizes the results of the welfare economic assessment in million $€$ per functional unit $\left(\mathrm{M} € \mathrm{FU}^{-1}\right)$ including only direct effects (direct effects) and including total effects (direct and indirect). In addition, it shows the variation of the results with respect to the distribution of the income effects. The distribution of the income effects only affect the externality costs associated and have little influence on the total results since the externality costs are two others of magnitude lower than the budget costs. Table S16 shows the externality costs associated with each item included in the income effect.

The welfare costs for: the WMS, Energy sector, Food industry, Agriculture and Industry results from the product of the expenses reported in Table S12 and the Net Tax Factor (assumed 1.17 for Denmark). ${ }^{77}$ The Tax Distorsion Loss resulted from: 1) the difference of the tax received by the State in the baseline scenario (Sc-IN) and the alternative scenarios (Sc-CD, Sc-AF and Sc-PR) from 
Table S12 and 2) the Tax Distortion factor (assumed 20\% for Denmark). ${ }^{77}$ The emissions consequences are calculated with the emissions from the LCA and the accounting prices of emissions (Table S11). And the Ecosystem losses were calculated as shown in Figure S2 and the tables of SI-IIIB.

Table S15: Social Life-Cycle Costing of the four scenarios assessed in $€$ per functional unit (M€/FU) including only direct effects (direct effects) and including total effects (direct and indirect).

\begin{tabular}{|c|c|c|c|c|c|c|c|c|c|}
\hline & & & & & -LCC & $(\mathrm{M} € / \mathrm{FL}$ & & & \\
\hline & & & Direct $\mathrm{I}$ & ffects & & & Total & Effects & \\
\hline & & IN & $\mathrm{CD}$ & $\mathrm{AF}$ & $\mathrm{PR}$ & IN & $\mathrm{CD}$ & $\mathrm{AF}$ & $\mathrm{PR}$ \\
\hline & Waste Management & 68 & 124 & 126 & 39 & 68 & 124 & 126 & 39 \\
\hline نे & Energy sector & -10 & -6 & -6 & -4 & -10 & -6 & -6 & -4 \\
\hline$\overleftarrow{\Delta ̆}_{0}$ & Food industry & 1132 & 1132 & 1132 & $\mathbf{0}$ & 1132 & 1132 & 1132 & $\mathbf{0}$ \\
\hline تِّ & Agriculture & $\mathbf{0}$ & -2 & -21 & $\mathbf{0}$ & $\mathbf{0}$ & -2 & -21 & $\mathbf{0}$ \\
\hline & Rebound effect - Industry & & & & & $\mathbf{0}$ & 32 & 38 & -1147 \\
\hline & Tax Distortion Loss & $\mathbf{0}$ & 3 & -1 & 48 & $\mathbf{0}$ & 4 & $\mathbf{0}$ & -1 \\
\hline & Emissions (direct effects) & 16 & 24 & 12 & -1 & 16 & 24 & 12 & -1 \\
\hline & -WMS (w/o avoided) & 3 & 3 & 3 & 1 & 3 & 3 & 3 & 1 \\
\hline & - Avoided energy & -3 & 5 & -4 & -2 & -3 & 5 & -4 & -2 \\
\hline & - Avoided NPK & 0 & 1 & -1 & 0 & 0 & 1 & -1 & 0 \\
\hline & - Avoided fodder & 0 & 0 & -2 & 0 & 0 & 0 & -2 & 0 \\
\hline$\frac{n}{n}$ & - Animal food production & 8 & 8 & 8 & 0 & 8 & 8 & 8 & 0 \\
\hline ن & - Vegetable food production & 8 & 8 & 8 & 0 & 8 & 8 & 8 & 0 \\
\hline 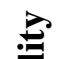 & Emissions (indirect effects) & & & & & 11 & 9 & 8 & 47 \\
\hline $\bar{\Xi}$ & Emissions income effects & & & & & 0 & -1 & -2 & 47 \\
\hline$\stackrel{\underline{u}}{\underline{u}}$ & Emissions iLUC & & & & & 11 & 11 & 9 & 0 \\
\hline & Ecosystem loss - ILUC & & & & & 3 & 3 & 2 & $\mathbf{0}$ \\
\hline & Ecosystem loss - AFW & & & & & 2 & 2 & 2 & 0 \\
\hline & Ecosystem loss - VFW & & & & & 1 & 1 & 1 & 0 \\
\hline & Ecosystem loss - Maize & & & & & & & -1 & \\
\hline & Accidents and noise externality & 1 & 3 & 2 & 1 & 1 & 3 & 2 & 1 \\
\hline & Collection & 1 & 3 & 2 & 1 & 1 & 3 & 2 & 1 \\
\hline & Transportation & 0 & 0 & 0 & 0 & 0 & 0 & 0 & 0 \\
\hline & Total & 1208 & 1278 & 1243 & 83 & 1221 & 1323 & 1293 & -1066 \\
\hline
\end{tabular}

\section{Results variation due to income effect distribution:}

\begin{tabular}{|l|r|rrrr|}
\hline Total (MAX) & & 1221 & 1321 & 1291 & -997 \\
\hline Total (MIN) & & 1221 & 1322 & 1292 & -1021 \\
\hline
\end{tabular}


Table S 16: Externality costs associated with the input/output process used in the income effects per $€ 2015$. The impact associated with the marginal consumption of the baseline results by income distribution shown in Table S4 and Figure 1 and these characterized impacts per item. The cells colored in red represent the maximum impact in each category given by a specific item whereas the greens represent the minimum impacts.

\begin{tabular}{|l|cccccc|c|}
\hline & \multicolumn{6}{|c|}{ Externality cost $(€$ emission / $€$ spend $)$} \\
\hline 133 Household use, Clothing, EU27 & CO2 & CH4 & N20 & Nox & SO2 & CO & Total \\
134 Household use, Communication, EU27 & 2E-02 & $1 \mathrm{E}-03$ & $1 \mathrm{E}-03$ & $1 \mathrm{E}-02$ & 3E-02 & 9E-06 & $6 \mathrm{E}-02$ \\
135 Household use, Education, EU27 & 2E-02 & $4 \mathrm{E}-04$ & $5 \mathrm{E}-04$ & $2 \mathrm{E}-02$ & $2 \mathrm{E}-02$ & $4 \mathrm{E}-05$ & $6 \mathrm{E}-02$ \\
136 Household use, Health care, EU27 & $5 \mathrm{E}-03$ & $3 \mathrm{E}-04$ & $2 \mathrm{E}-04$ & $4 \mathrm{E}-03$ & $7 \mathrm{E}-03$ & $3 \mathrm{E}-06$ & $2 \mathrm{E}-02$ \\
137 Household use, Housing, EU27 & $5 \mathrm{E}-03$ & $3 \mathrm{E}-04$ & $5 \mathrm{E}-04$ & $4 \mathrm{E}-03$ & $8 \mathrm{E}-03$ & $4 \mathrm{E}-06$ & $2 \mathrm{E}-02$ \\
138 Household use, Hygiene, EU27 & $1 \mathrm{E}-02$ & $7 \mathrm{E}-04$ & $4 \mathrm{E}-04$ & $8 \mathrm{E}-03$ & $2 \mathrm{E}-02$ & $8 \mathrm{E}-06$ & $4 \mathrm{E}-02$ \\
139 Household use, Leisure, EU27 & $5 \mathrm{E}-02$ & $3 \mathrm{E}-03$ & $9 \mathrm{E}-04$ & $2 \mathrm{E}-02$ & $5 \mathrm{E}-02$ & $3 \mathrm{E}-05$ & $1 \mathrm{E}-01$ \\
140 Household use, Meals, EU27 & $1 \mathrm{E}-02$ & $1 \mathrm{E}-03$ & $1 \mathrm{E}-03$ & $1 \mathrm{E}-02$ & $2 \mathrm{E}-02$ & $3 \mathrm{E}-05$ & $5 \mathrm{E}-02$ \\
141 Household use, Security, EU27 & $1 \mathrm{E}-02$ & $5 \mathrm{E}-03$ & $5 \mathrm{E}-03$ & $1 \mathrm{E}-02$ & $2 \mathrm{E}-02$ & $1 \mathrm{E}-05$ & $6 \mathrm{E}-02$ \\
\hline Marginal Cost (baseline) & $5 \mathrm{E}-04$ & 3E-05 & 2E-05 & 5E-04 & 7E-04 & 4E-07 & 2E-03 \\
\hline
\end{tabular}

\section{Food composition importance}

Figure S3 illustrate costs/impacts of the different food commodities included in the baseline and alternative composition of the edible food waste. 
A.
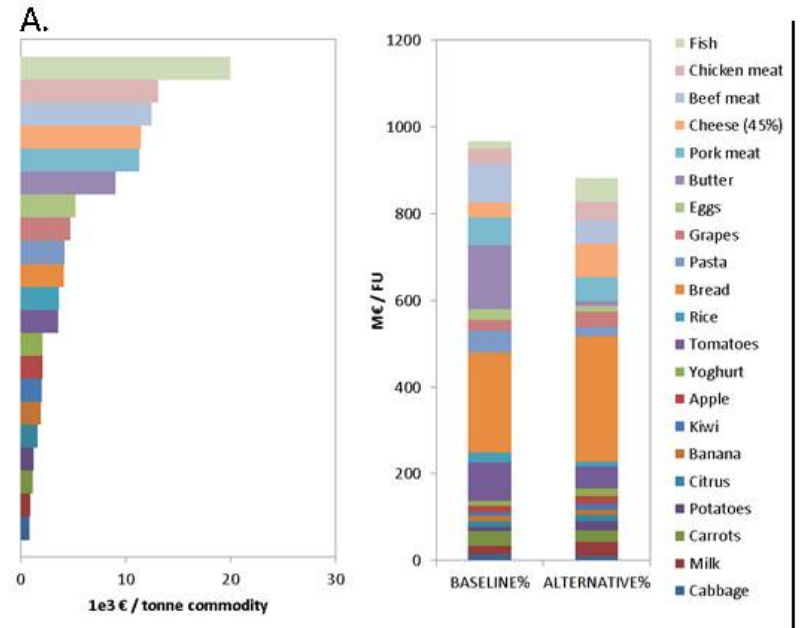

B.
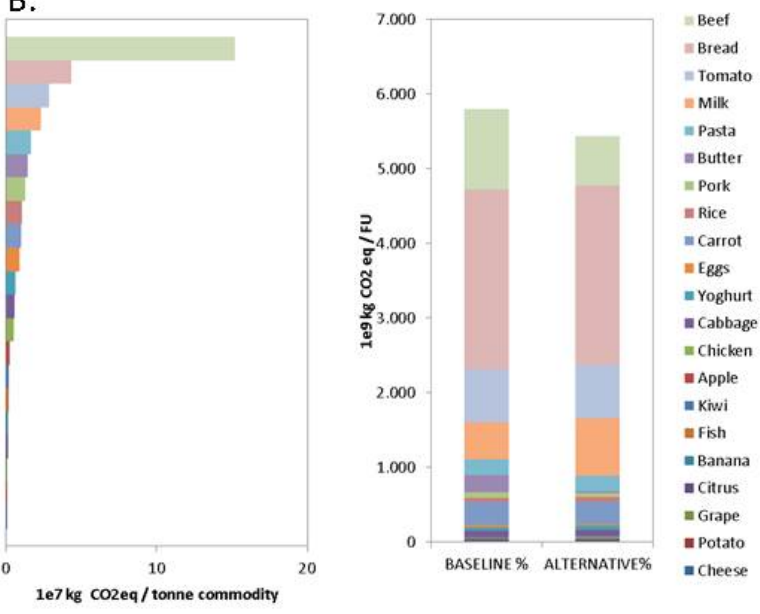

c.
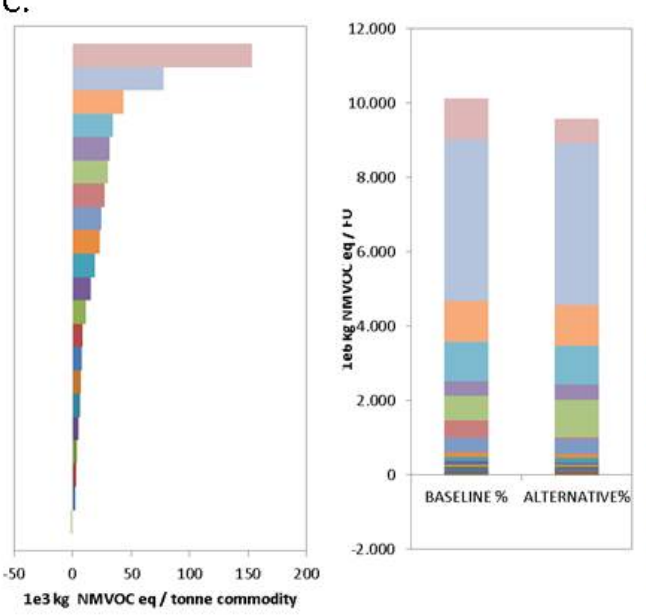

=Beef

"Beef
$=$ Bread

= Bread
= Tomato
=Carrot

=Carrot

- Pa

In Milk

= Butter
= Cabbage

$=$ Pork

= Rice

- Eggs

\#Apple

=Chicken
-Yoghurt

Fish

- Banana

- Kiwi

=citrus

- Grape

Cheese

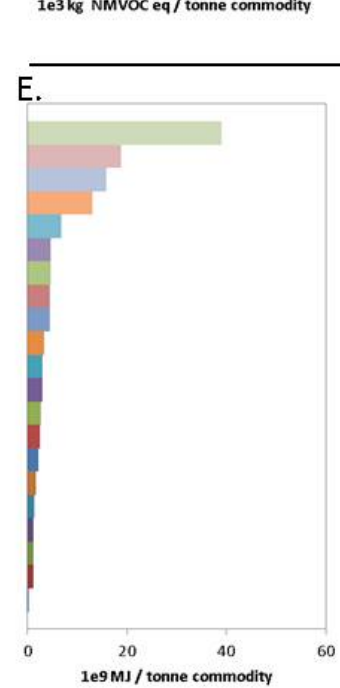

D.
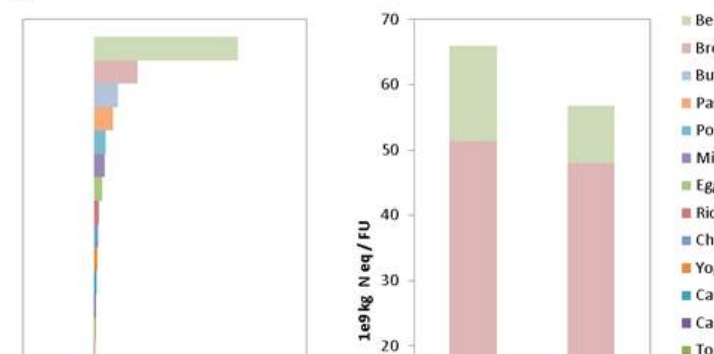

Beef

Butter

Pasta

Eggs

Rice

Chicken

= Yoghurt

= Carrot

- Cabbage

- Baman

= Potato

= Fish

= Kiwi

- Apple

- Citrus

arape

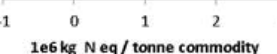

-cheese
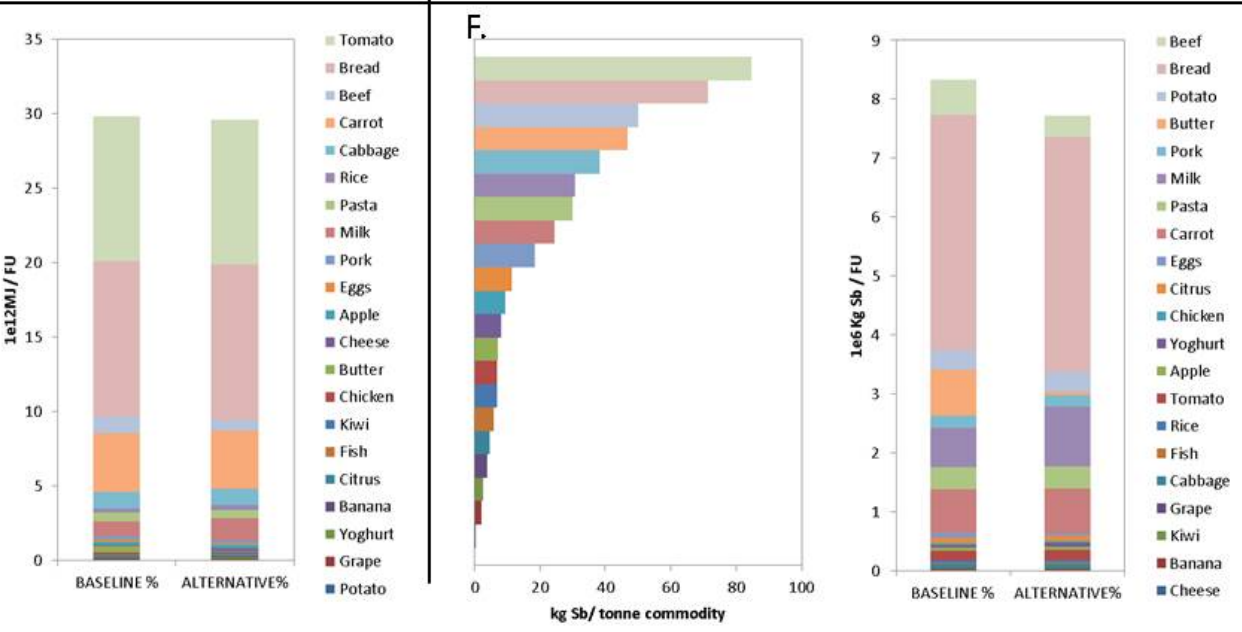

Figure S3 Intrinsic impact of each food commodity (per tonne of commodity) and the contribution of each commodity into the impact of the functional unit (FU). A) Budget costs (factor prices), B) Global warming (kg CO2 eq), C) Photechemical Ozone Formation (kg NMVOC eq), D) Marine eutrophication ( $\mathrm{kg} \mathrm{N}$ eq), E) Fossil resource depletion (MJ) and F) mineral resource depletion (kg $\mathrm{Sb})$. 


\section{E. Uncertainties results:}

Including food transportation and handling (associated with the edible food waste) would correspond to an average driving distance (by car) of $28 \mathrm{~km} \mathrm{week}^{-1}$ households ${ }^{-1}$ and electricity consumption (per meal) of $1 \mathrm{MJ} .^{78,79}$ This increases the financial costs of the first three scenarios by approximately 4\%: $19 \mathrm{M} €$ related to home transportation (allocating only 54\% of the total distance to the edible food waste, i.e. weight percentage of the edible food waste in the total food waste, and assuming $100 \mathrm{~km}^{\text {liter }}$ diesel $^{-1}$ and $1 €$ liter diesel ${ }^{-1}$ ) and $10 \mathrm{M} €$ associated with the electricity consumed for cooking etc. in the extreme scenario in which all the edible food waste is cooked before being thrown (assuming $0.5 \mathrm{~kg} \mathrm{meal}^{-1}$ and $20 € \mathrm{GJ}^{-1}$ electricity). At the same time, the income effects of S-PR adjust to the cost of S-IN, i.e. it increases by $30 \mathrm{M} €$ ( $3 \%$ of the income effects of this scenario) and all the scenarios shown the same financial costs.

This inclusion also increases the GW of all the scenarios, by $100 \%$ for the three scenarios and by $3 \%$ in the S-PR scenario and the ranking between scenarios remains the same but the difference among them decreases. The transportation increases the GW impact by $2.610^{8} \mathrm{~kg} \mathrm{CO}_{2}$ (assuming $132 \mathrm{~g} \mathrm{CO}_{2} \mathrm{~km}$ driving with diesel car) and the electricity consumption by $5.910^{7} \mathrm{~kg} \mathrm{CO}_{2}$ (assuming $0.47 \mathrm{~kg} \mathrm{CO}_{2} \mathrm{MJ}^{-1}$ electricity. The ranking of the scenarios in the Societal LCC is not affected by the inclusion, but the difference between them increases (i.e. the first three scenarios adds $35.1 \mathrm{M} €$ (30 $M € * 1.17)$ while the S-PR increases the social benefit by the same amount in terms of income effects. 
VIII. References:

(1) Kortlaegning af dagrenovation i enfamilieboliger; ISBN nr. 978-87-92779-94-6; Miljoestyrelsen: Denmark, 2012. http://www2.mst.dk/Udgiv/publikationer/2012/05/978-8792779-94-6.pdf.

(2) Kortlaegning af dagrenovation i Danmark. Med fokus paa etageboliger og madspild; ISBN nr. 978-87-93178-52-6; Miljoestyrelsen: Denmark, 2014. http://www2.mst.dk/Udgiv/publikationer/2014/05/978-87-93178-52-6.pdf.

(3) Danish food prices in 2013 (data available upon request via http://www.dst.dk/en/kontakt); Statistics Denmark, 2015.

(4) Household yearly consumption by type of consumption, group of households and price unit 2011:2013; Statistics Denmark, 2015. http://www.statbank.dk/FU5.

(5) Beretta, C.; Stoessel, F.; Baier, U.; Hellweg, S. Quantifying food losses and the potential for reduction in Switzerland. Waste Manag. 2013, 33, 764-773.

(6) Household Food and Drink Waste linked to Food and Drink Purchases; DEFRA, 2010.

(7) Quested, T.; Johnson, H. Household Food and Drink Waste in the UK: A Report Containing Quantification of the Amount and types of Household Food and Drink Waste in the UK. Report Prepared by WRAP (Waste and Resources Action Programme), Banbury.; 2009.

(8) Weidema, B. P. Marginal production technologies for life cycle inventories. Int. J. Life Cycle Assess. 1999, 4, 48-56.

(9) Market information in life cycle assessment; Danish Environmental Protection Agency; Environmental Project No. 863; Denmark , 2003. http://www.norlca.org/resources/780.pdf.

(10) Our future energy; ISBN 978-87-7844-917-7; Danish Goverment: Denmark, 2011. www.ens.dk/sites/ens.dk/files/policy/danish-climate-energy-policy/our_future_energy.pdf.

(11) Forudsaetninger for samfundsoekonomiske analyser paa energiomraadet; ISBN nr. 978-8793071-90-2; Energistyrelsen: Denmark, 2014. http://www.ens.dk/info/talkort/fremskrivninger-analyser-modeller/samfundsokonomiske-beregnings-forudsaetninger.

(12) Tonini, D.; Hamelin, L.; Astrup, T. F. Environmental implications of the use of agroindustrial residues for biorefineries: application of a top-down model for indirect land-use changes. GCB Bioenergy 2015.

(13) International Fertilizer Industry Association Website; http://www.fertilizer.org/Statistics.

(14) Danish Food Composition Databank; National Food Institute Website; http://www.foodcomp.dk/v7/fcdb_search.asp.

(15) Feedipedia: An on-line encyclopedia of animal feeds | Feedipedia - Animal Feed Resources Information System http://www.feedipedia.org/.

(16) Thiesen, J.; Christensen, T. S.; Kristensen, T. G.; Andersen, R. D.; Brunoe, B.; Gregersen, T. K.; Thrane, M.; Weidema, B. P. Rebound effects of price differences. Int. J. Life Cycle Assess. 2006, 13, 104-114.

(17) Simapro 7. Database Manual. EU \& DK Input Output Database. Product Ecology Consultants (PRE), 2010. https://www.presustainability.com/download/manuals/DatabaseManualEU-DKIODatabase.pdf.

(18) Searchinger, T. Use of U.S. Croplands for Biofuels Increases Greenhouse Gases Through 
Emissions from Land-Use Change. Science 2008, 319, 1238-1240.

(19) Vázquez-Rowe, I.; Marvuglia, A.; Rege, S.; Benetto, E. Applying consequential LCA to support energy policy: land use change effects of bioenergy production. Sci. Total Environ. 2014, 472, 78-89.

(20) Land Use Changes and Consequent CO2 Emissions due to US Corn Ethanol Production: A Comprehensive Analysis; Department of Agricultural Economics Purdue University, 2010. http://www.transportation.anl.gov/pdfs/MC/625.PDF.

(21) Kløverpris, J.; Wenzel, H.; Nielsen, P. H. Life cycle inventory modelling of land use induced by crop consumption. Int. J. Life Cycle Assess. 2007, 13, 13-21.

(22) Tonini, D.; Hamelin, L.; Wenzel, H.; Astrup, T. Bioenergy production from perennial energy crops: a consequential LCA of 12 bioenergy scenarios including land use changes. Environ. Sci. Technol. 2012, 46, 13521-13530.

(23) Broch, A.; Hoekman, S. K.; Unnasch, S. A review of variability in indirect land use change assessment and modeling in biofuel policy. Environ. Sci. Policy 2013, 29, 147-157.

(24) Asquith, N. M.; Vargas, M. T.; Wunder, S. Selling two environmental services: In-kind payments for bird habitat and watershed protection in Los Negros, Bolivia. Ecol. Econ. 2008, $65,675-684$.

(25) Edwards, S. The demand for Galapagos vacations - Estimation and application to wilderness preservation. Costal Manag. 1991, 19, 155-169.

(26) Godoy, R.; Overman, H.; Demmer, J.; Apaza, L.; Byron, E.; Huanca, T.; Leonard, W.; Pérez, E.; Reyes-García, V.; Vadez, V.; et al. Local financial benefits of rain forests: comparative evidence from Amerindian societies in Bolivia and Honduras. Ecol. Econ. 2002, 40, $397-$ 409.

(27) Grimes, A. Valuing the rainforest - The economic value of nontimber forest products in Ecuador. Ambio 1994, 23, 405-410.

(28) Horton, B.; Colarullo, G.; Bateman, I. J.; Peres, C. A. Evaluating non-user willingness to pay for a large-scale conservation programme in Amazonia: a UK/Italian contingent valuation study. Environ. Conserv. 2003, 30, 139-146.

(29) Naidoo, R.; Ricketts, T. H. Mapping the economic costs and benefits of conservation. PLoS Biol. 2006, 4, e360.

(30) Muñiz-Miret, N.; Vamos, R.; Hiraoka, M.; Montagnini, F.; Mendelsohn, R. O. The economic value of managing the açaí palm (Euterpe oleracea Mart.) in the floodplains of the Amazon estuary, Pará, Brazil. For. Ecol. Manage. 1996, 87, 163-173.

(31) Núñez, D.; Nahuelhual, L.; Oyarzún, C. Forests and water: The value of native temperate forests in supplying water for human consumption. Ecol. Econ. 2006, 58, 606-616.

(32) Pinedo-Vasquez, M. Economic returns from forest conversion in the Peruvian Amazon. Ecol. Econ. 1992, 6, 163-173.

(33) Rausser, G. Valuing research leads bioprospecting and the conservation of genetic resources. J. Polit. Econ. 2000, 108, 173-206.

(34) Torras, M. The total economic value of Amazonian deforestation, 1978-1993. Ecol. Econ. 2000, 33, 283-297.

(35) Keeping the Amazon forests standing: a matter of values; WWF, 2009. 
http://www.wwf.se/source.php/1229304/Keeping the Amazon forests standing.pdf.

(36) Viglizzo, E. F.; Frank, F. C. Land-use options for Del Plata Basin in South America: Tradeoffs analysis based on ecosystem service provision. Ecol. Econ. 2006, 57, 140-151.

(37) Adger, N.; Brown, K.; Cervigni, R.; Moran, D. Towards estimating total economic value of forests in Mexico: CSERGE Working Paper GEC 94-21; 1994.

(38) Ammour, T.; Windervoxhel, N.; Sencion, G. Economic valuation of mangrove ecosystems and sub-tropical forests in Central America. In Sustainable Forest Management and Global Climate Change: Selected Case Studies from the Americas; Dore, M. H. I.; Guevara, R., Eds.; 2000.

(39) Eade, J. D. O.; Moran, D. Spatial Economic Valuation: Benefits Transfer using Geographical Information Systems. J. Environ. Manage. 1996, 48, 97-110.

(40) Echeverría, J. Valuation of non-priced amenities provided by the biological resources within the Monteverde Cloud Forest Preserve, Costa Rica. Ecol. Econ. 1995, 13, 43-52.

(41) Godoy, R.; Lubowski, R.; Markandya, A. A method for the economic valuation of nontimber tropical forest products. Econ. Bot. 1993, 47, 220-233.

(42) Paying for biodiversity conservation services in agricultural landscapes; World Bank, Paper No. 96; 2004.

(43) Ricketts, T. H.; Daily, G. C.; Ehrlich, P. R.; Michener, C. D. Economic value of tropical forest to coffee production. Proc. Natl. Acad. Sci. U. S. A. 2004, 101, 12579-12582.

(44) Shultz, S.; Pinazzo, J.; Cifuentes, M. Opportunities and limitations of contingent valuation surveys to determine national park entrance fees: evidence from Costa Rica. Environ. Dev. Econ. 1998, 3, 131-149.

(45) Tobias, D. Valuing Ecotourism in a tropical rainforest reserve. Ambio 1991, 20, 91-93.

(46) Case studies of markets and innovative financial mechanisms for water services from forests; Forest Trends, 2001.

(47) Loomis, J.; Ekstrand, E. Alternative approaches for incorporating respondent uncertainty when estimating willingness to pay: the case of the Mexican spotted owl. Ecol. Econ. 1998, 27, 29-41.

(48) Chomitz, K. M.; Kumari, K. The Domestic Benefits of Tropical Forests: A Critical Review Emphasizing Hydrological Functions: Policy Research Working Papers; 1601; 1995.

(49) Tianhong, L.; Wenkai, L.; Zhenghan, Q. Variations in ecosystem service value in response to land use changes in Shenzhen. Ecol. Econ. 2010, 69, 1427-1435.

(50) Kumari, K. Sustainable forest management: Myth or reality? Exploring the prospects for Malaysia. Ambio 1996, 25, 459-467.

(51) Priess, J. A.; Mimler, M.; Klein, A.-M.; Schwarze, S.; Tscharntke, T.; Steffan-Dewenter, I. Linking Deforestation Scenarios to pollination services and economic returns in coffee agroforestry systems. Ecol. Appl. 2007, 17, 407-417.

(52) van Beukering, P. J. .; Cesar, H. S. .; Janssen, M. A. Economic valuation of the Leuser National Park on Sumatra, Indonesia. Ecol. Econ. 2003, 44, 43-62.

(53) An Economic Valuation of the terrestrial and marine resources of Samoa. WWF UK, 2001.

(54) Niskanen, A. Value of external environmental impacts of reforestation in Thailand. Ecol. 
Econ. 1998, 26, 287-297.

(55) Bann, C. An Economic Analysis of Tropical Forest Land Use Options, Ratanakiri Province, Cambodia; EEPSEA Research Report Series; 1997.

(56) Cruz, W.; Francisco, H. A.; Tapawan-Conway, Z. The On-Site and Downstream Costs of Soil Erosion; Philippine Institute for Development studies; 88-11; 1988.

(57) Hodgson, G.; Dixon, J. A. logging versus tourism and fisheries. Trop. Coast. Area Manag. 3(1) 5-8 1988.

(58) Rosales, M. P. R.; Kallesoe, M. F.; Pauline, G.; Muangchanh, P.; Phomtavong, S.; Khamsomphou, S. Balancing the Returns to Catchment Management: The Economic Value of Conserving Natural Forests in Sekong, Lao PDR. IUCN Water, Nat. Econ. Tech. Pap. No. 5.

(59) Naidoo, R.; Adamawiczm, W. L. Biodiversity and nature-based tourism at forest reserves in Uganda. Environ. Dev. Econ. 2005, 10, 159-178.

(60) Turpie, J. K.; Heydenrych, B. J.; Lamberth, S. J. Economic value of terrestrial and marine biodiversity in the Cape Floristic Region: implications for defining effective and socially optimal conservation strategies. Biol. Conserv. 2003, 112, 233-251.

(61) Yaron, G. Forest, Plantation Crops or Small-scale Agriculture? An Economic Analysis of Alternative Land Use Options in the Mount Cameroon Area. J. Environ. Plan. Manag. 2001, 44, 85-108.

(62) Mount Kenya: The economics of community conservation; Evaluating Eden Series Discussion Paper No.4, 1999.

(63) George, C.; Kajembe, G. C.; And, M.; Mvena, Z. S. K. Making community-based forest management work: a case study from Duru-Haitemba village forest reserve, Babati, Arusha, the United Republic of Tanzania. In 2nd International Workshop on Participatory Forestry in Africa.; 2000.

(64) Curtis, I. A. Valuing ecosystem goods and services: a new approach using a surrogate market and the combination of a multiple criteria analysis and a Delphi panel to assign weights to the attributes. Ecol. Econ. 2004, 50, 163-194.

(65) Mallawaarachchi, T.; Blamey, R. K.; Morrison, M. D.; Johnson, A. K.; Bennett, J. W. Community values for environmental protection in a cane farming catchment in northern Australia: a choice modelling study. J. Environ. Manage. 2001, 62, 301-316.

(66) Blackwell, B. D. The Economic Value of Australia's Natural Coastal Assets: Some Preliminary Findings http://www.researchgate.net/publication/238584799_The_Economic_Value_of_Australia's_ Natural_Coastal_Assets_Some_Preliminary_Findings.

(67) Martinez-Sanchez, V.; Kromann, M. A.; Astrup, T. F. Life cycle costing of waste management systems: Overview, calculation principles and case studies. Waste Manag. 2015, 36, 343-355.

(68) Esteban, M. B.; García, A. J.; Ramos, P.; Márquez, M. C. Evaluation of fruit-vegetable and fish wastes as alternative feedstuffs in pig diets. Waste Manag. 2007, 27, 193-200.

(69) StatBureau. Inflation Rate Eurozone. https://www.statbureau.org/.

(70) Berlin, J.; Sonesson, U.; Tillman, A.-M. Product Chain Actors' Potential for Greening the 
Product Life Cycle. J. Ind. Ecol. 2008, 12, 95-110.

(71) Bevilacqua, M.; Braglia, M.; Carmignani, G.; Zammori, F. A. Life Cycle Assessment of Pasta production in Italy. J. Food Qual. 2007, 30, 932-952.

(72) Forudsætninger for samfundsøkonomiske analyser på energiområdet; ISBN 978-87-7844895-8; Energistyrelsen, 2011.

http://www.ens.dk/sites/ens.dk/files/dokumenter/publikationer/downloads/forudsaetninger_fo r_samfundsoekonomiske_analyser_paa_energiomraadet_2011.pdf.

(73) Analysis method for welfare economic costs of mitigation measures in the Climate Policy Plan; Energistyrelsen, 2013.

(74) Transportøkonomiske Enhedspriser; Technical University of Denmark, Department of Transportation, 2014.

(75) Beregningspriser for luftemissioner - 2007; Danmarks Miljoeundersoegelser, 2007. http://www2.dmu.dk/Pub/EVA-beregningspriser.pdf.

(76) Miljoe- og samfundsoekonomisk vurdering af muligheder for oeget genanvendelse af papir, pap, plast, metal og organisk affald fra dagrenovation; Miljoeprojekt nr. 1458;

Miljoeministeriet: Denmark, 2013. http://www2.mst.dk/Udgiv/publikationer/2013/01/97887-92903-80-8.pdf.

(77) Samfundsoekonomisk vurdering af miljoeprojekter; ISBN: 978-87-92548-71-9; Miljoeministeriet: Denmark, 2010. http://www2.mst.dk/udgiv/publikationer/2010/978-8792548-71-9/pdf/Endelig Vejledning i samfunds\%C3\%B8konomisk vurdering af milj\%C3\%B8projekter_net.pdf.

(78) Sonesson, U.; Anteson, F.; Davis, J.; Sjödén, P.-O. Home Transport and Wastage: Environmentally Relevant Household Activities in the Life Cycle of Food. AMBIO A J. Hum. Environ. 2005, 34, 371-375.

(79) Sonesson, U.; Mattsson, B.; Nybrant, T.; Ohlsson, T. Industrial Processing versus Home Cooking: An Environmental Comparison between Three Ways to Prepare a Meal. AMBIO A J. Hum. Environ. 2005, 34, 414-421. 